\title{
Maccullochella ikei, an Endangered Species of Freshwater Cod (Pisces: Percichthyidae) from the Clarence River System, NSW and $M$. peelii mariensis, a New Subspecies from the Mary River System, Qld
}

\author{
STUART J. ROWLAND \\ NSW Fisheries, Eastern Freshwater Fish Research Hatchery, \\ Grafton, NSW 2460, Australia
}

\begin{abstract}
The eastern freshwater cod, Maccullochella ikei, from the Clarence River system, NSW, is described and M. peelii mariensis is described as a new subspecies from the Mary River system, Qld. The Murray cod, M. p. peelii and the trout cod, M. macquariensis, are indigenous to the Murray-Darling River system. Using electrophoretic data for 19 presumed loci, the coefficient of genetic identity between M. p. peelii and M. ikei was 0.72 and the banding-patterns of the muscle general protein, liver esterases and five other enzymes, were species-specific. A high proportion of abnormal and inviable hybrid larvae in a cross-breeding experiment indicate that post-zygotic isolating mechanisms have evolved between $M$. p. peelii and $M$. ikei. The coefficient of genetic identity between $M$. p. peelii and $M . p$. mariensis was 0.85 and banding patterns of muscle general protein were diagnostic. Canonical variates analysis using 18 morphological and nine meristic characters, clearly separated both spccics and the subspecies. Maccullochella ikei is distinguished from $M$. p. peelii by having longer pelvic fins, larger orbit length, and larger and morphologically distinct sagittal otoliths. Maccullochella p. mariensis differs from M. p. peelii by the combination of a deeper and shorter caudal peduncle, longer pelvic fins, larger sagittal otoliths and lesser extension of the first anal pterygiophore towards the first caudal vertebra, and from M. ikei by the combination of a deeper caudal peduncle, greater postorbital head length, smaller orbit, larger interorbital width, fewer scale rows below the lateral line, shorter fifth-sixth dorsal spine and lesser extension of the first anal pterygiophore. Although each species has distinctive colouration and mottling, there is some intra-specific variation. Maccullochella macquariensis is distinct from the other species by having a straight head profile, jaws of similar length, 14 precaudal vertebrae and distinctive colouration. There was a dramatic reduction in the distribution and abundance of cod in the eastern drainage during the early 1900 s and cod were probably extinct in the Richmond and Brisbane River systems by the end of the 1930s. Maccullochella ikei and M. p. mariensis are each represented by one, small population. Possible causes of the decline, and the management strategies taken to conserve the endangered M. ikei are discussed.
\end{abstract}


Rowland, S.J., 1993. Maccullochella ikei, an endangered species of freshwater cod (Pisces: Percichthyidae) from the Clarence River system, NSW and M. peelii mariensis, a new subspecies from the Mary River system, Qld. Records of the Australian Museum 45(2): 121-145.

The Murray cod Maccullochella peelii peelii (Mitchell, 1838 ) is an Australian native warmwater fish which grows to over $50 \mathrm{~kg}$ and is highly regarded because of its size and excellent angling and edible qualities. Murray cod, although no longer common (Rowland, 1989), are found naturally throughout much of the Murray-Darling River system (Fig.1). The trout cod, M. macquariensis (Cuvier, 1829) which was once sympatric with $M$. p. peelii in the southern tributaries of the Murray-Darling River system (Berra \& Weatherley, 1972), is now found only in the Murray River between Yarrawonga Weir and Tocumwal, and in the upper reaches of Seven Creeks (Ingram et al., 1990) and has been classified as endangered
(Harris, 1987).

Murray cod have been introduced into numerous waters outside their natural range including the Cox's, Mulwaree, Nepean and Wollondilly Rivers, Cataract Dam, and several other Sydney water supply dams in the eastern drainage of central NSW (Rowland, 1989). Freshwater cod have also been recorded from the Clarence, Richmond, Brisbane and Mary River systems in the eastern drainage of northern NSW and southern Queensland, but there has always been doubt as to the taxonomic status and origin of the cod in these coastal rivers (Ogilby, 1893, 1895; Anderson, 1916; Lake, 1971). Wilcox (1863) stated that Mr J. Macleay identified a 'Murray River cod' from the Urara

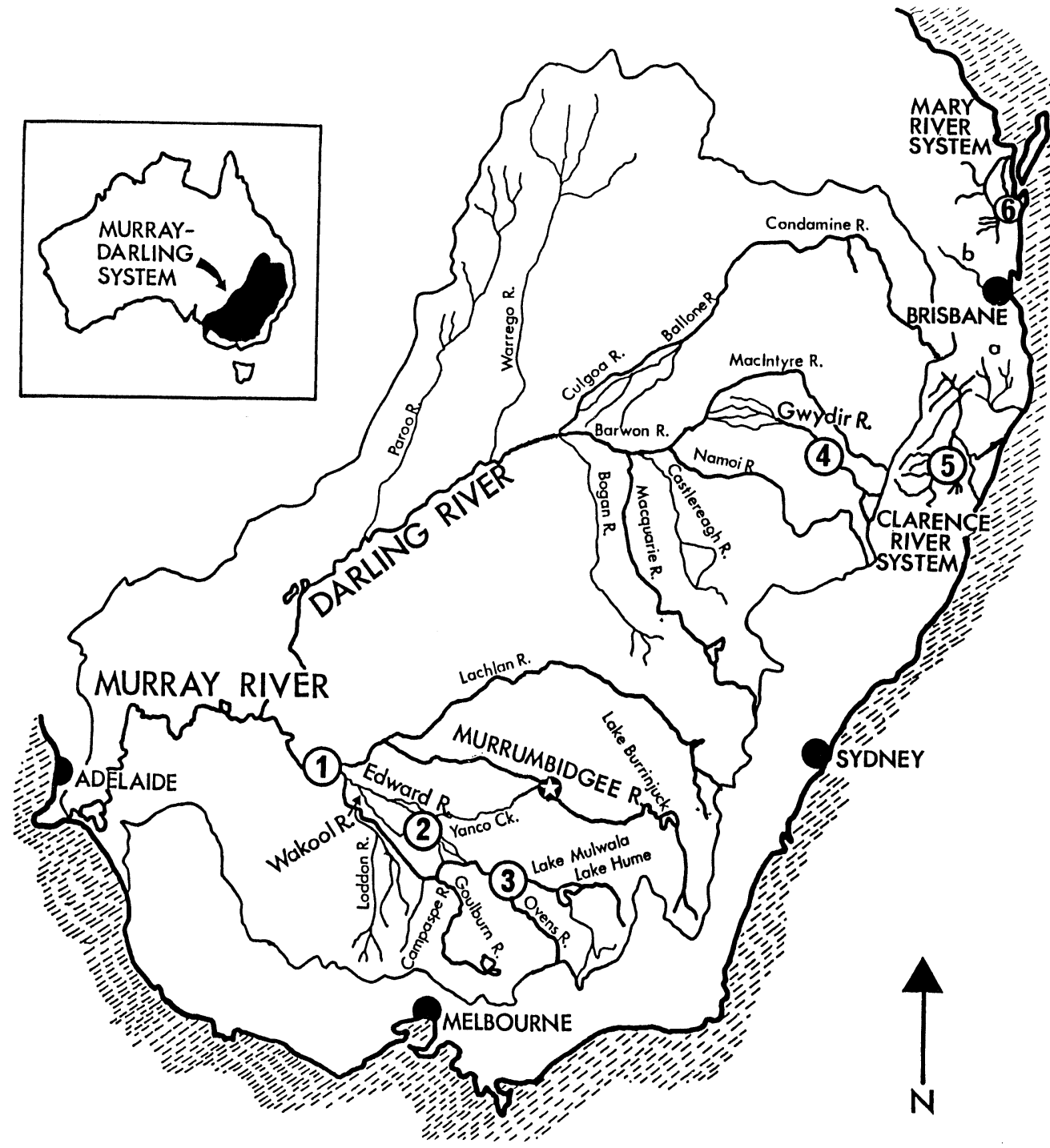

Fig.1. The Murray-Darling, Clarence and Mary River systems: (a) Richmond River system, (b) Brisbane River system. Sampling sites: 1. Murray River; 2. Edward and Wakool Rivers; 3. Lake Mulwala; 4. Gwydir and MacIntyre Rivers; 5. Mann and Nymboida Rivers; 6. Six-mile, Coondoo and Tinana Creeks. Star in circle - Inland Fisheries Research Station. 
[sic] (The Orara River is a tributary of the Clarence River) and Hill (1864) stated that Mr James Devlin, who had lived on both the Murrumbidgee and Clarence Rivers, considered that the codfish of the Urara [sic] were identical to those of the western waters. Macleay (1887) obtained a cod from the Richmond River and after comparing it carefully with specimens of Oligorus macquariensis and $O$. mitchelli [synonyms of $M$. p. peelii and M. macquariensis respectively (Berra \& Weatherley, 1972; MacDonald, 1978)] considered that it resembled the latter.

The naturalists on the Challenger expedition recorded $O$. macquariensis from the Mary River (Ogilby, 1895), and O'Connor (1897) stated that the Murray cod, $O$. macquariensis, was known to occur in the upper part of the Brisbane River. McCulloch and Whitley (1925) also recorded $O$. macquariensis from these two rivers as well as the tributaries of the Darling River in Queensland. Two forms of cod - 'sharp-nose' and 'boof-headed' are currently recognised in the Mary system (Merrick \& Schmida, 1984), and experienced anglers have long recognised morphological and biological differences between cod from the Mary River and those from the Murray-Darling system in southern Queensland (J. Winkel, personal communication).

Whitley (1937) and Berra \& Weatherley (1972) included museum specimens of cod from the Mary River in their systematic reviews of Maccullochella, but details of the number and size of these specimens were not given. MacDonald (1978) did not include cod from the eastern drainage in his review of the systematics of Australian freshwater percichthyid fishes. The cod population in the Clarence River system was recognised as a distinct species by Rowland (1985) and a description of Maccullochella ikei n.sp., without details of the type material, was published by Rowland (1986). In the current paper, the research to determine the taxonomic status of the cod populations in the eastern drainage is detailed. Data on the type material of $M$. ikei are presented, and $M$. peelii mariensis is described as a new subspecies from the Mary River system. Historical records were examined, and residents of north-eastern NSW and south-eastern Queensland were interviewed to enable a qualitative comparison of the past and present distribution and abundance of cod in the eastern drainage.

\section{Materials and Methods}

General. Cod were sampled from the Murray-Darling, Clarence and Mary systems (Fig.1). In addition, Murray cod that had been artificially bred at the Inland Fisheries Research Station (IFRS) and stocked into farm dams near Narrandera, were sampled when one to three years old. The number and range in standard length (SL) of cod sampled from each site are given in Table 1 [Appendix]. After capture, morphometric data were recorded and liver tissue and muscle tissue from midway between the base of the pelvic fin and the anus, were removed from some specimens, frozen and kept at $-20^{\circ} \mathrm{C}$ until required for electrophoresis. Additional specimens of cod from the Clarence system were examined live in the field, under anaesthetic, and released.

All measurements and counts were made on fresh specimens with the exception of those for the type specimens which were made within two months of fixation in $10 \%$ formalin and preservation in $70 \%$ alcohol. In the descriptions, proportions and counts for the lectotype of $M$. ikei and the holotype of $M . p$. mariensis are followed, in parentheses, by the range of each character for the paralectotypes, paratypes, other material and other specimens. AMS and QM are prefixes for specimens lodged at the Australian Museum, Sydney and Queensland Museum, Brisbane respectively.

All tables are listed in the Appendix.

Electrophoresis. Electrophoresis was carried out on slab polyacrylamide gels, horizontal starch gels and cellulose acetate sheets using techniques described by Shaw \& Prasad (1970), Keenan \& Shaklee (1985) and Shaklee \& Keenan (1986). Details of the six electrophoretic systems used are given in Table 2 and the proteins that were assayed, the systems and tissues used and the number of cod analysed are given in Table 3 . Tissues for starch gel and cellulose acetate electrophoresis were homogenised in a lysing solution $\left(100 \mathrm{~mL} \mathrm{H}_{2} 0,2\right.$ drops MCE, $100 \mathrm{uL} \mathrm{NaDP}$ ) and centrifuged at $5000 \mathrm{rpm}$ for $5 \mathrm{~min}$ at $4^{\circ} \mathrm{C}$. Presumptive gene loci are labelled with an italicised abbreviation for the enzyme (Table 3) and multiple loci for a given enzyme are distinguished by numerals, with 1 representing the most anodally migrating isozyme. Allozymes of common mobility are interpreted as if encoded by the same allele. Alleles were designated by their relative mobility, with the most anodal being 100 .

The genetic identity and genetic distance between cod from the Murray-Darling, Clarence and Mary systems were estimated using the coefficient of genetic identity (I) and genetic distance ( $\mathrm{D}=-1 \mathrm{n}$ I) as defined by Nei (1972). Values of I can range from 0 where the populations being compared share no alleles, to 1 , where all alleles are common and have the same frequency. Estimates of the divergence times between cod in the different systems were calculated using $\mathrm{t}=5 \times 10^{6} \mathrm{D}(\mathrm{Nei}$, 1975) where $t=$ time since divergence in years, and $D$ $=$ genetic distance.

Morphometrics. Meristics and morphological measurements follow Hubbs \& Lagler (1974) except where stated. The respective measurements were made on the left side of the fish where possible using a measuring board (to the nearest $1 \mathrm{~mm}$ ) and vernier callipers (to nearest $0.1 \mathrm{~mm}$ ). The post-orbital and orbit lengths, the inter-orbital width and the width between the posterior nares were least-fleshy measurements. Body depth I is the distance between the base of the first dorsal spine and the base of the pelvic fin and body depth II is the maximum depth when the fish is held 
vertically by the lower jaw. The length of the pelvic fin was measured from the base of the fin to the tip of the longest filament when extended.

Data on the 27 characters listed in Tables 6 and 7 , plus the number of spines in the anal fin, the number of rays in the pelvic fin and the number of pyloric caecae were recorded. Head characters were expressed as a percentage of head length (HL) and all other measurements, including HL, were expressed as a percentage of SL for each specimen. These data were subjected to a canonical variates analysis (CVA; Reyment et al., 1984). Only cod with values for all characters listed in Tables 6 and 7 except body depth I were included in the analysis. The first and second canonical variates were plotted to identify the distinct forms of cod, and the canonical structures were listed to identify the main characters contributing to the variation. The means of each morphometric character for cod from the Clarence system, the Mary system and Murray cod from rivers and farm dams were then compared using Student's t-tests; this analysis was also used to compare the means of the characters for Murray cod from rivers and farm dams and from Lake Mulwala. To reduce the effect of allometric growth of the various body parts on the analysis, only Murray cod (with the exception of those sampled from Lake Mulwala) that were within the length range of cod sampled from the Clarence and Mary systems were analysed. Berra \& Weatherley (1972) found that eye diameter and the length of the longest dorsal spine grew allometrically in Murray cod, and so the means of all characters except orbit length and the length of the fifth or sixth dorsal spine were compared between populations of Murray cod.

Osteology. X-rays were made of preserved specimens of Murray cod ( $n=3)$, trout cod (3), and cod from the Clarence (4) and Mary (5) systems. The predorsal bones, and the precaudal and caudal vertebrae were counted in each specimen. In this study, vertebrae anterior to the vertebra associated with the first anal pterygiophore were classified as precaudal vertebrae. The length of the first anal pterygiophore was measured (on the X-rays) and expressed as a percentage of the distance from the base of this pterygiophore to the ventral surface of the first caudal vertebra.

Otoliths. The lengths and widths of otoliths from five Murray cod (total length, TL 420-625 mm), five cod from the Clarence system (TL 330-489 mm) and four cod from the Mary system (TL 420-610 mm) were measured using vernier callipers and expressed as a percentage of the TL for each fish. The otoliths were then lightly smeared with graphite to emphasise external morphological features and compared.

Cross-breeding experiment. Four cod (1 male, 3 females) were captured from the Clarence system and transported live to the IFRS for use in a cross-breeding experiment with Murray cod that had originally been captured from the Murrumbidgee River. All cod were held in earthen ponds until October. Experiments involving cod from the Mary River system and trout cod were not conducted because of the logistical problems with catching, transporting and maintaining the broodfish, the limited facilities at IFRS and the general difficulty of breeding freshwater cod.

Techniques for the handling, injection of human chorionic gonadotrophin (HCG), stripping, and the fertilisation and incubation of eggs are described by Rowland (1988a). The only male cod from the Clarence system died after the injection of HCG and so reciprocal crosses involving this male were not possible. Milt from two Murray cod males were used to fertilise eggs. The eggs from each female were incubated in separate troughs at temperatures ranging from 20 to $24^{\circ} \mathrm{C}$. The hatch rate of eggs from each female was determined by expressing the number of larvae that hatched as a percentage of the number of eggs incubated. Larvae from each batch of eggs were sampled daily and examined microscopically, and differences between Murray cod and hybrid larvae were noted.

\section{Results}

Electrophoresis - general proteins. The phenotypes of general protein following polyacrylamide gel electrophoresis of cod muscle tissue are shown in Figure 2 . The banding patterns at three zones $(1,2,3)$ were diagnostic for cod from each of the three systems; cod from the Clarence and Mary systems differed at zone 1 , cod from the Clarence and Murray cod at zones 2 and 3, and cod from the Mary system differed from Murray cod at all three zones. The banding patterns of Murray cod from all sampling sites (including Lake Mulwala; No. 24) were indistinguishable, with the exception of fish No. 1 which had a distinct band anodal to the diagnostic fast band at zone 3 (Fig.2). This cod was from the Gwydir River in northern NSW Fish No. 4 was also from this river and its banding pattern was identical to that of all other specimens of Murray cod.

Enzymatic proteins. The ten loci encoding the first eight enzymes listed in Table 3 were monomorphic and fixed for the same allele in all cod. The most anodal isozyme of aspartate amino-transferase (Aat- 1 ) consisted of two bands and the isozymes of the other nondiagnostic enzymes consisted of single, generally intensely-staining bands. The malate dehydrogenase isozyme consisted of two bands, with the most anodal band having greater intensity in tissue from Murray cod and cod from the Mary system, whereas the cathodal band stained more intensely in tissue of cod from the Clarence system. Allelic frequencies at loci of diagnostic enzymes after starch gel and cellulose acetate electrophoresis of cod muscle and liver tissue are given in Table 4. 
Mannose-6-phosphate isomerase (MPI). The enzyme MPI varies genetically in a wide variety of organisms but generally behaves as a monomer exhibiting singlebanded homozygotes (Shaklee, 1983). All cod examined had a single, intensely-staining band at one locus, Mpi-1. Murray cod and cod from the Clarence system were fixed for alternative alleles $(100,87)$ at this locus, and cod from the Mary system were fixed for the allele characteristic of Murray cod.

Isocitrate dehydrogenase (IDH). The $\mathrm{NADP}^{+}-$ dependent IDH of teleost fishes often appears in both supernatant and mitochondrial forms (Engel et al., 1971; Wheat et al., 1973). Two isozymes of IDH were observed after electrophoresis of cod muscle tissue and the lack of interlocus heterodimers suggests that the observed phenotypes represent one supernatant and one mitochondrial loci. All cod were fixed for the same allele at $I d h-1$, but Murray cod and cod from the Clarence system were fixed for alternative alleles at $I d h-2$. The phenotypes at this locus of cod from the Mary system were not determined.

L-iditol dehydrogenase (IDDH). Two loci control the expression of IDDH phenotypes in cod liver tissue. At Iddh-1, Murray cod and cod from the Clarence system were fixed for alternative alleles $(100,88)$. Five cod from the Mary system displayed the allele characteristic of Clarence fish but one cod (captured from Tinana Creek) displayed the allele characteristic of Murray cod. No heterozygous forms were observed and the cod from Tinana Creek was otherwise electrophoretically identical to the other cod from the Mary system.
Glucose-6-phosphate isomerase (GPI). GPI in fishes is a dimeric molecule and multiple isozymes result from the interaction of subunits (Avise \& Kitto, 1973). Two types of subunits predominate in nearly all tissues (Shaklee et al., 1974). The GPI phenotypes observed after electrophoresis of cod muscle tissue were presumed to represent the homodimers $G p i-A_{2}$ and $G p i-B_{2}$ and the $A B$ heterodimer. $G p i-B_{2}$ did not stain intensely although slight variation was evident, different phenotypes were not allocated to individual fish. $G p i-A_{2}$ stained intensely. Murray cod and cod from the Mary system were fixed for the 'fast' band and cod from the Clarence were fixed for the 'slow' band.

Glycerol-3-phosphate dehydrogenase (G3PDH). Broad bands of G3PDH activity were apparent after starch gel electrophoresis of cod muscle tissue. There were two relative mobilities of the bands - 'fast' and 'slow' - and it was assumed that these represented alleles at a single G3PDH locus. Again, Murray cod and cod from the Clarence system were fixed for alternative alleles (100, 90) and the cod from the Mary system all had the allele characteristic of Murray cod.

Glucose-6-phosphate dehydrogenase (G6PDH). Multiple allozymes were resolved by electrophoresis of cod liver tissue, but positive interpretation was not possible because the molecular and genetic bases of teleost G6PDH are poorly understood (Shaklee et al., 1974). It is tentatively proposed that two loci control the expression of G6PDH phenotypes in cod liver tissue and that there are five alleles at the $G 6 p d h-1$ locus. Other possible interpretations of the observed phenotypes are

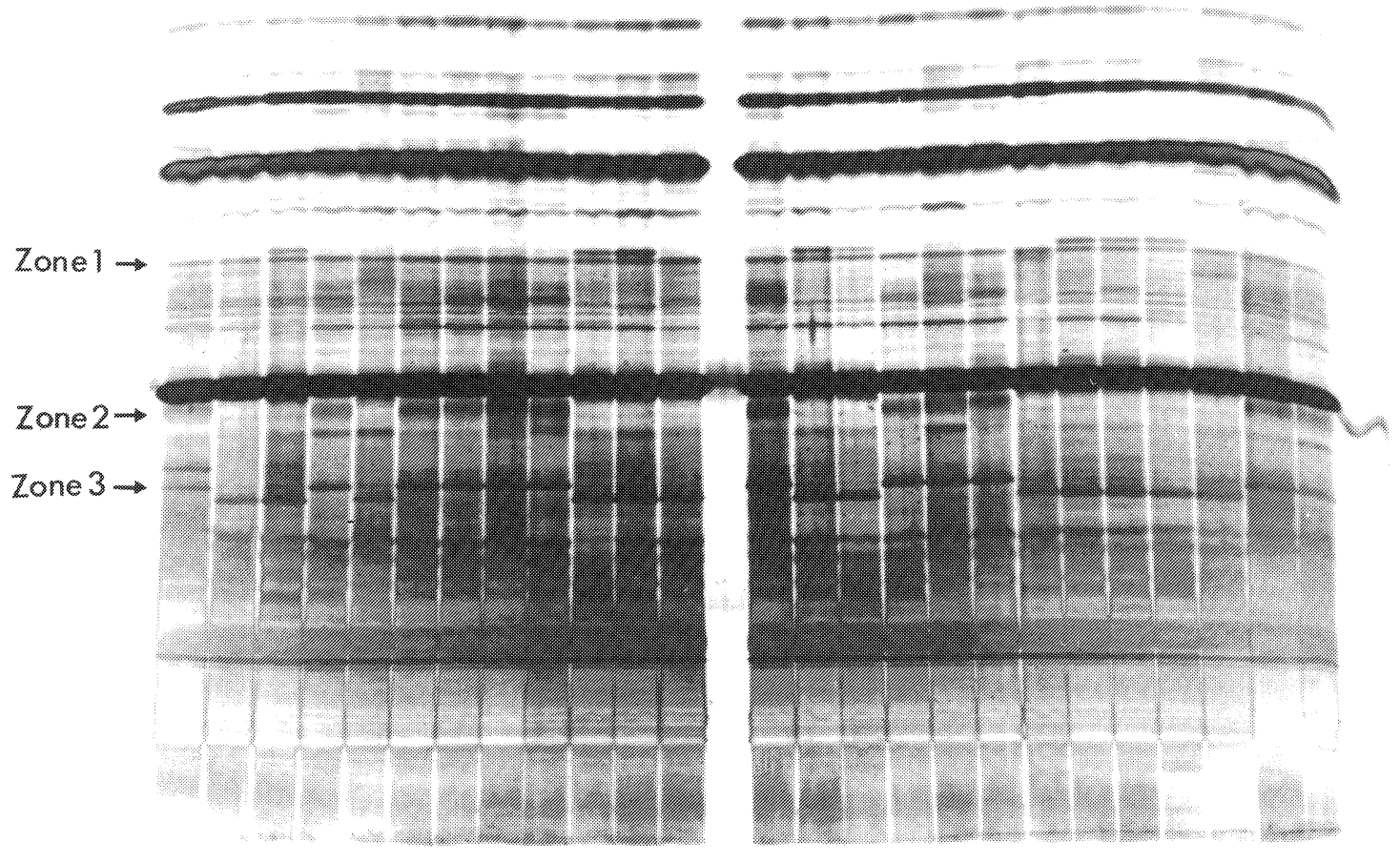

Fish No. 1234456789101112

13141516171819202122232425

Fig.2. General protein phenotypes of cod after polyacrylamide gel electrophoresis of muscle tissue. Maccullochella p. peelii: fish nos 1, 4, 6, 7, 8, 9, 13, 16, 17, 18, 24, 25; Maccullochella ikei: fish nos 2, 5, 12, 19, 23; Maccullochella p. mariensis: fish nos 3, 10, 11, 14, 15, 20, 21, 22. 
multiple loci, heterodimers and post-translation changes. There was a significant difference $\left(X^{2}=183.56, d f=8, P\right.$ less than 0.005) in the frequency of the presumed alleles at G6pdh-1 between Murray cod and cod from the Clarence and Mary systems. The two alleles $(92,69)$ with the highest frequency in Murray cod, were either absent or present at low frequencies in cod from the eastern drainage (Table 4). Although there appeared to be some variation at $G 6 p d h-2$, resolution of this locus was relatively poor and so different phenotypes were not allocated to individual fish.

Esterases (EST). There were three major zones of activity in cod liver tissue and at zone 2, bands of different mobility characterised Murray cod and cod from the Clarence system. EST phenotypes of cod from the Mary system were not determined because of poor resolution.

Genetic identity, genetic distance and time since divergence. Electrophoretic data from 19 loci were used to calculate the coefficients of genetic identity. The data for general protein, esterases, malate dehydrogenase $\left(\mathrm{NADP}^{+}\right)$and $G 6 p d h-2$ were not used because the genetic basis of the former two proteins is not known and the interpretation of phenotypes at $M d h\left(N A D P^{+}\right)-1$ and G6pdh-2 was uncertain.

The coefficients of genetic identity (I) and the genetic distance (D) between Murray cod, cod from the Clarence and Mary systems and trout cod [data from MacDonald (1978)] are given in Table 5.

The electrophoretic data derived from the enzymatic proteins strongly suggest that cod in the Clarence system represent a separate species to $M$. p. peelii ( $\mathrm{I}=0.72$, $\mathrm{D}=0.33$ ) and that the population is not conspecific with cod in the Mary system ( $I=0.73, D=0.32)$. The electrophoretic data also suggest that the cod population in the Mary system is more closely related to $M$. p. peelii $(\mathrm{I}=0.85, \mathrm{D}=0.16)$ than to $\operatorname{cod}$ in the Clarence system.

The estimates of the time of divergence of $M . p$. peelii and cod in the Clarence and Mary systems from a

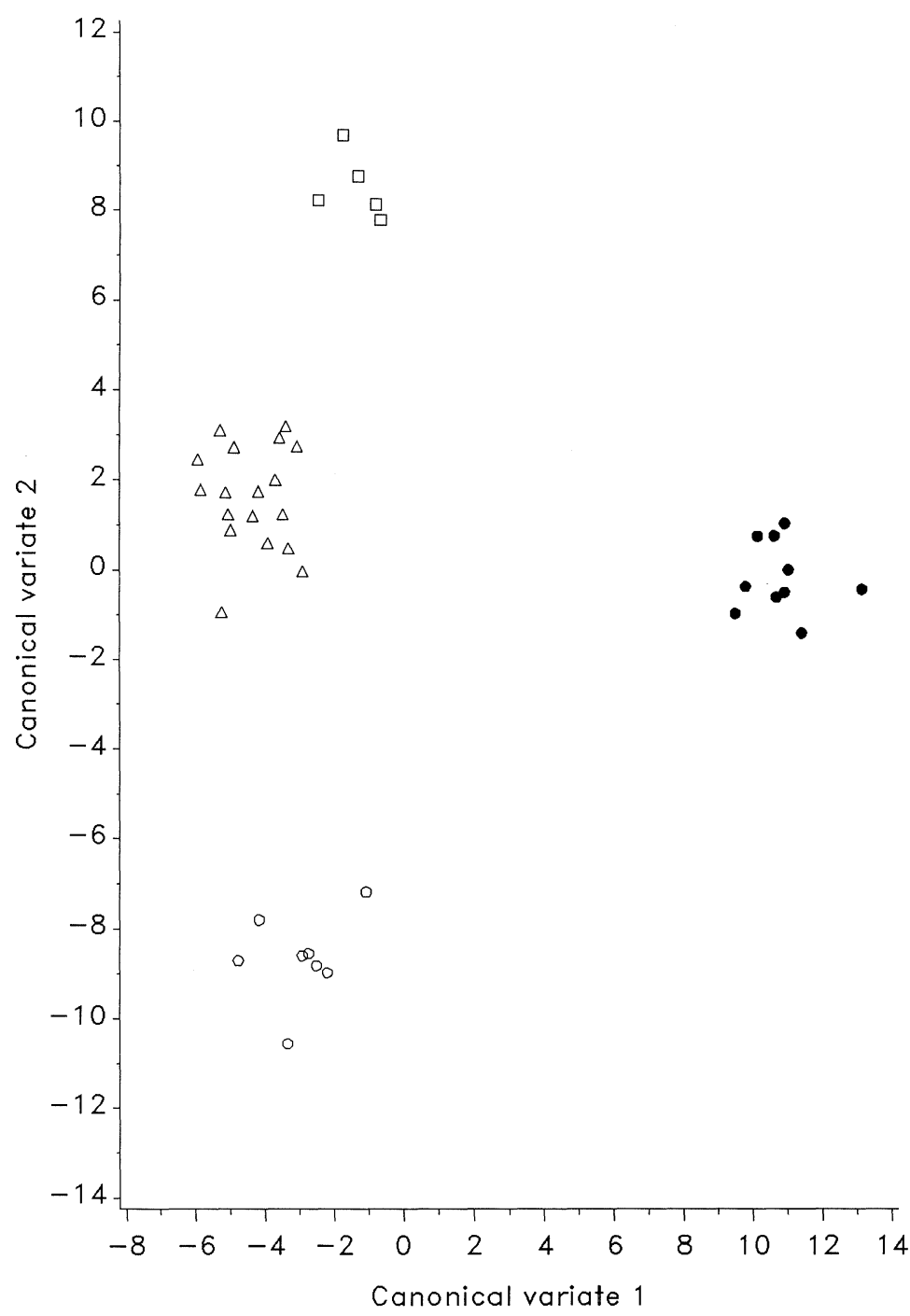

Fig.3. Plot of first and second canonical variates. Dot - M. ikei, circle $-M$. p. mariensis, square - M. $p$. peelii ex Lake Mulwala, triangle $-M$. p. peelii ex rivers and farm dams. 
common ancestor are 1.7 and 0.8 million years ago (mya) respectively.

Morphometrics - canonical variates analysis. The number of spines in the anal fin (3), rays in the pelvic fin (5) and pyloric caecae (4) were the same in all cod examined and hence not entered into the CVA. The CVA of the remaining 27 characters separated cod into four distinct groups: cod from the Clarence system; cod from the Mary system; Murray cod from rivers and farm dams; Murray cod from Lake Mulwala (Fig.3). Cod from the Clarence system were separated from the other populations by the first canonical variate on the basis of postorbital head length, scale rows below the lateral line, length of the fifth/sixth dorsal spine, length of the pelvic fin and interorbital width. The second canonical variate separated the remaining three populations on the basis of length of pelvic fin, anal base, depth of caudal peduncle, and orbit length.

The means of seven morphometric characters differed significantly ( $\mathrm{P}$ less than 0.01 ) between Murray cod from the rivers (and farm dams) and those sampled from Lake Mulwala (Table 6). These data demonstrate substantial intraspecific morphological variation between populations in rivers and small, impounded waters and those in large, impounded waters.

Comparison of Murray cod and cod from the Clarence system. These cod have distinctive colouration. Cod from the Clarence system are generally yellow-green to golden with black to very dark green, heavily reticulated mottling on the dorsal surface, head and sides, whereas in Murray cod the colour ranges from cream to olive to yellow-green with relatively smaller, pale to dark green mottling often with small dark spots between the reticulation (Fig.4). The pelvic fin of Clarence cod is clear, whereas in Murray cod this fin is usually whitish.

The means of 13 morphometric characters differed significantly ( $\mathrm{P}$ less than 0.01 ) between Murray cod and cod from the Clarence system (Table 7). The ranges of the length of the pelvic fin (expressed as a percentage of SL) do not overlap, thus providing a diagnostic character. The second filament on the first ray of the pelvic fin is usually extended in cod from the Clarence system compared to Murray cod (Fig.4). The fine tip of this filament may be damaged or missing in preserved specimens. Orbit length is also diagnostic.

Cod from the Mary system. These cod differ significantly ( $\mathrm{P}$ less than 0.01 ) in ten characters from Clarence cod and in five characters from Murray cod (Table 7). Although there is no single morphometric character which is completely diagnostic because the ranges of all characters overlap, a combination of characters enables diagnosis. These data and the results of the CVA indicate that cod from the Mary system are morphometrically more similar to Murray cod. However, the means of the length of the pelvic fin (expressed as a percentage of SL) were significantly different ( $\mathrm{P}$ less than 0.001), and the range of this character in the Mary system population lay mainly within the range of the character for the Clarence population (Table 7). The relatively long pelvic fin is therefore common to the populations of cod in the eastern drainage. Cod in the Mary system also have a dark, heavily reticulated mottled pattern, similar to cod in the Clarence system (Fig.4).

\section{Osteology}

Cod from the Clarence system and Murray cod had a total of 35 vertebrae, consisting of 15 precaudal and 20 caudal vertebrae. The three trout cod examined each had 14 precaudal and 21 caudal vertebrae and three of the five cod from the Mary system had 35 (15 +20 ) vertebrae, while the other two had only 34 (15 + 19) vertebrae (Table 8). The extension of the first anal pterygiophore towards the first caudal vertebra is greater in Murray cod and cod from the Clarence system than in trout cod and cod from the Mary system.

\section{Otoliths}

The sagittal otoliths of Maccullochella spp. are relatively large and long (length:width, 2.2-2.8:1), and show some inter-specific differences. Otoliths of cod from the Clarence system (otolith length $3.2-3.5 \%$ of fish TL) and the Mary system (2.9-3.3\% TL) are larger than otoliths from similar-sized Murray cod (2.5-2.9\% TL). In cod from the Clarence system the anterior edge of the rostrum of each otolith is more rounded and has a distinctly smaller antirostrum than otoliths in Murray cod. The medial dorsal surface is slightly indented whereas in Murray cod this surface is slightly convex. The morphology of otoliths in cod from the Mary system appears intermediate to those in Murray cod and cod from the Clarence system.

\section{Cross-breeding Experiment}

The results of the hormone-induced breeding trials are presented in Table 9. Dosages of 500 and $1000 \mathrm{IU} / \mathrm{kg}$ HCG did not induce ovulation in cod from the Clarence system, however, as expected (Rowland, 1988a) ovulation had commenced in female Murray cod $48 \mathrm{~h}$ after the injection of $1000 \mathrm{IU} / \mathrm{kg} \mathrm{HCG}$. Two batches of eggs were stripped after different latent periods from each female. The hatch rates of eggs stripped 48 and $48 \mathrm{~h}$ after injection were 3 and $58 \%$ respectively, and the hatch rates of eggs stripped 49 and $50 \mathrm{~h}$ after injection were 90 and $75 \%$. Approximately 96,200 eggs were stripped and a total of 50,125 larvae hatched. All larvae underwent normal development during yolk sac 

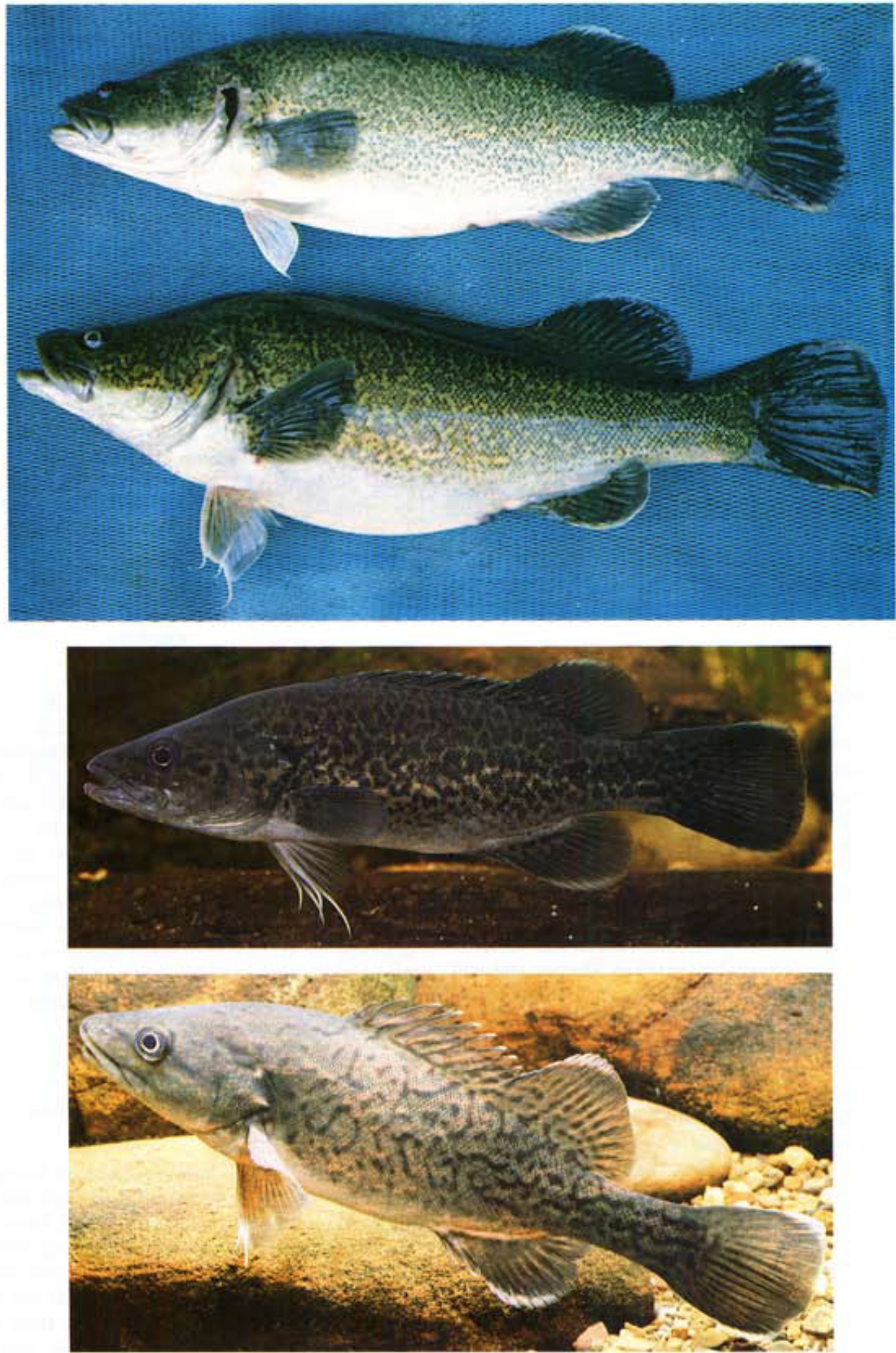

Fig.4. (top) Maccullochella peelii peelii (female, $495 \mathrm{~mm} \mathrm{SL}, 554 \mathrm{~mm}$ TL, $3.1 \mathrm{~kg}$ total weight, left operculum damaged), (upper middle) Maccullochella ikei (female, $515 \mathrm{~mm} \mathrm{SL}, 610 \mathrm{~mm} \mathrm{TL}, 3.4 \mathrm{~kg}$ total weight) (photographed live, under anaesthetic by Ken Bock), (lower middle) Maccullochella peelii mariensis n.subsp. (photograph, Gunther Schmida) (bottom) Maccullochella macquariensis ( $250 \mathrm{~mm}$ TL) (photograph, Gunther Schmida). 
absorption, confirming that the milt from the two males was viable.

Ovulation had commenced in a female cod from the Clarence system $46 \mathrm{~h}$ after the injection of $2000 \mathrm{IU} / \mathrm{kg}$ HCG. Approximately 6,750 eggs were stripped and fertilised using milt from the two Murray cod males. An additional 1,900 eggs were stripped and fertilised two hours later. Hatching commenced $120 \mathrm{~h}$ after fertilisation. A total of 777 eggs hatched ( $9 \%$ hatch rate), comprising $147(2 \%)$ of those stripped $46 \mathrm{~h}$ after injection and 630 (33\%) stripped after $48 \mathrm{~h}$ (Table 9).

Most hybrid larvae that hatched from both batches of eggs were obviously deformed. The deformities ranged from gross malformations of the head, body and tail (Fig.5a) to scoliosis and/or lordosis (Fig.5b). Other abnormalities observed in most hybrid larvae were: malformation of the fins, in particular the caudal and pectoral fins; the lack of, or decreased size of the oil droplet; a relatively pale pink colour of blood in comparison to the bright red blood of Murray cod larvae. Abnormal larvae of Murray cod are very uncommon even when hatch rates are low due to suboptimal induced-spawning conditions (Rowland, 1988a).

There were also some developmental differences between Murray cod and the small number of apparently 'normal' hybrid larvae. The oil droplet in these hybrid larvae was spherical and positioned below the gills, whereas in Murray cod larvae the oil droplet was ovalshaped and situated below the eyes (Fig.6). The cardiac cavity, when viewed laterally, was distinctly narrower in Murray cod than in hybrid larvae.

At the completion of yolk sac absorption, approximately ten days after the completion of hatching, only 226 hybrid larvae were alive ( $29 \%$ of the total that had hatched). At this stage of development, hybrid larvae averaged 10.7 $\mathrm{mm}$ TL $(\mathrm{n}=12)$ and were significantly smaller $(\mathrm{t}=10.3$, $P$ less than 0.01) than same-aged Murray cod larvae, that averaged $13 \mathrm{~mm}$ TL $(\mathrm{n}=12)$. Most hybrid larvae were much less active and died within two weeks of yolk sac absorption.

The abnormalities observed in hybrid larvae, the high mortalities during and after yolk sac absorption and the developmental differences between Murray cod and
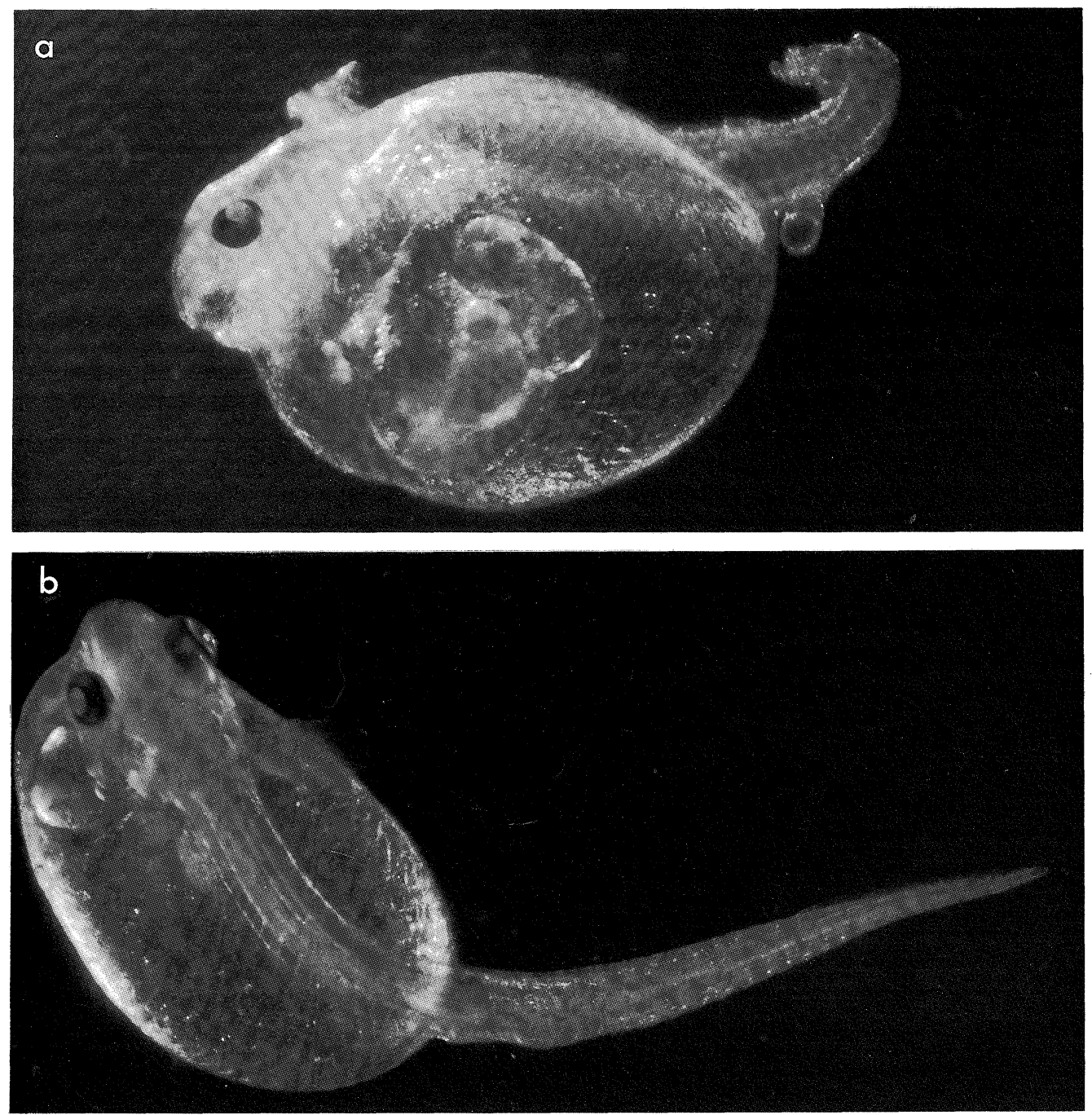

Fig.5. Abnormal larvae (50 h old) from a cross between eastern freshwater cod and Murray cod (x22), (a) grossly abnormal larva, (b) larva with scoliosis (photograph, P.M. Selosse). 


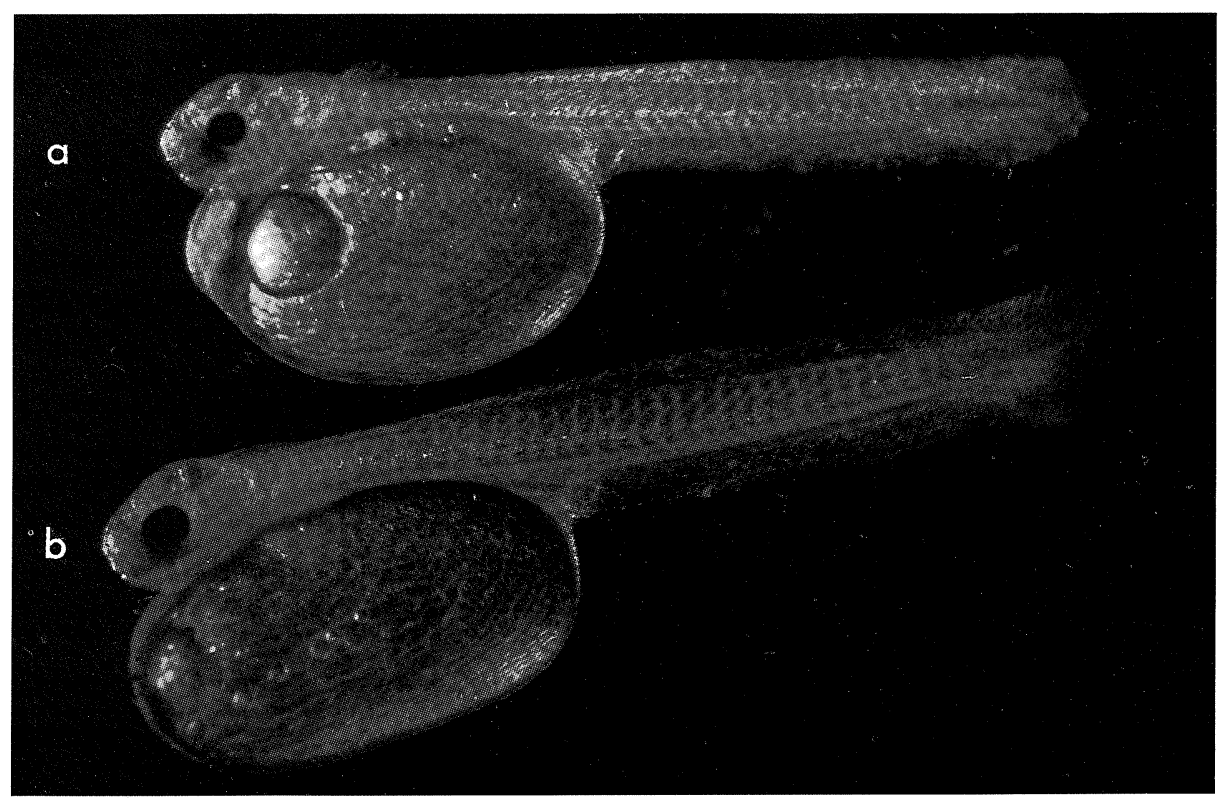

Fig.6. Cod yolk sac larvae $72 \mathrm{~h}$ old (x15), (a) from cross between eastern freshwater cod and Murray cod and (b) Murray cod (photograph, P.M. Selosse).

hybrid larvae, suggest that hybrid breakdown was occurring and that post-zygotic isolating mechanisms have evolved between $M . p$. peelii and the cod in the Clarence system.

As a result of the morphological and genetic differences between $M . p$. peelii and cod from the Clarence system, and the inviability of hybrid larvae, the eastern freshwater cod is considered to be a distinct species.

Maccullochella ikei Rowland, 1986

eastern freshwater cod

Fig.7

Gristes peelii.-Bennett, 1864: 81 (in part, in rivers of the eastern ranges).

Macquaria peelii.-Anon., 1859: 5 (large fish from Eurara [sic] River donated to Australian Museum by Mr Wilcox.).Angas, 1860: 5 (from the Clarence River presented by $\mathrm{Mr}$ J.F. Wilcox).

Oligorus macquariensis.-Macleay et al., 1880: 36 (in part, in branches of the Clarence).-Tenison-Woods, 1883: 103 (in part, in a few of the eastern rivers to the north of Sydney).Ogilby, 1886: 13 (in part, northern rivers of the eastern watershed of NSW).-Ogilby, 1893: 19 (in part, found in some of the northern coastal rivers of the Colony).Thompson, 1893: 21 (in part, in Clarence system).Ogilby, 1895: 71, 72 (in part, native of the Richmond and Clarence Rivers district).-McCulloch, 1922: 46, 57 (in part, in the headwaters of some northern streams).MuCulloch, 1927: 57 (in parts, the headwater of some northern streams).

Oligorus mitchelli.-Macleay, 1887: 981, 982 (in part, specimen from Richmond River).
Maccullochella macquariensis.-Whitley, 1937: 126 (in part, Richmond and Clarence systems).-Lake, 1959: 5 (in part, 2 coastal rivers - the Richmond and Clarence).-Lake, 1967: 31 (in part, in a few coastal streams in northern NSW).Roughley, 1968: 133 (in part, headwaters of Richmond and Clarence Rivers).-Lake, 1971: 33 (in part, Clarence and Richmond Rivers).-Grant, 1987: 435 (in part, Clarence and Richmond Rivers).

Maccullochella peeli.-Berra \& Weatherley, 1972: 60, 61 (in part, Clarence River).-Lake, 1978: 49 (in part, Clarence and Richmond Rivers).-MacDonald, 1978: 668 (in part, Clarence and Richmond Rivers).-Llewellyn \& MacDonald, 1980: 143 (in part, Richmond and Clarence Rivers).-Pollard et al., 1980: 246 (in part, Richmond and Clarence Rivers).Llewellyn, 1983: 15 (in part, north coast rivers, possibly introduced).

Maccullochella sp.-Merrick \& Schmida, 1984: 201 (Clarence River).-Harris, 1987: 8, 39 (coastal NSW rivers).-Allen, 1989: 138, 142, 143 (Clarence River system).-Ingram et al., 1990: 179, 180 (Clarence River system).-Pollard et al., 1990: 74 (eastern freshwater cod).

Maccullochella ikei Rowland, 1986: 16,17 (Clarence River system).

Maccullochella ikei.-Rowland, 1985 (unpublished): iv, 23-66 (Clarence River system).-Rowland, 1988b: 18, 19, 20, 22 (Clarence River system).-Rowland, 1988c: 168, 170 (some southern tributaries of the Clarence River system).-Hoser, 1991: 60 (Clarence River system).

Type material. LeCTOTYPE, AMS I.31090-001, $410 \mathrm{~mm}$, female, NSW, Nymboida River, at junction with Mann River (29 $\left.39^{\prime} \mathrm{S} 152^{\circ} 30^{\prime} \mathrm{E}\right)$, granite rocks and gravel to $4 \mathrm{~m}$, angled, K. Clark, 21 Nov. 1984. PARAlectotyPES, QM I27990, $422 \mathrm{~mm}$, female, Mann River, $2 \mathrm{~km}$ upstream of junction with Nymboida River (293'ㅇ $\left.152^{\circ} 29^{\prime} \mathrm{E}\right), 1 \mathrm{~m}$, angled, R. Cockbain, 8 June 1982; AMS I.31089-001, 385 $\mathrm{mm}$, female, same location as lectotype, angled, R. Lockwood, 21 Nov. 1984; $503 \mathrm{~mm}$, female, same location as 
lectotype, angled, C. Graham, 31 Sept. 1981 (specimen lost).

Other material. AMS I.31090-002, 2: 407-410 mm, males, Mann River, $6 \mathrm{~km}$ upstream of Jackadgery (29 $37^{\prime} \mathrm{S}$ $\left.152^{\circ} 33^{\prime} \mathrm{E}\right)$, gill net, S. Rowland, 12 Apr. 1986; AMS I.31090001 , 2: 305-320 mm, immature, same location as lectotype, gill net, S. Rowland, 13 Apr. 1986; QM I27991, 395 mm, female, Nymboida River, Ramornie State Forest (294's $\left.152^{\circ} 34^{\prime} \mathrm{E}\right), 2 \mathrm{~m}$, angled, G. Stewart, 7 Apr. 1987; QM I27992, $355 \mathrm{~mm}$, female, same locality as lectotype, gill net, $\mathrm{S}$. Rowland, 27 Sept. 1987; AMS I.31092-001, 355 mm, female Nymboida River, Buccarumbi $\left(2^{\circ} 51^{\prime} \mathrm{S} 152^{\circ} 35^{\prime} \mathrm{E}\right), 3 \mathrm{~m}$, angled, F. Prokop, 4 May 1988; AMS I.31093-001, 2: 375$456 \mathrm{~mm}$, males, same location as preceding, 1-3 m, angled, F. Prokop \& G. Stewart, 18 May 1988; QM I27993, 440 mm, male, same location as preceding, $2 \mathrm{~m}$, angled, K. Clark, 3 Aug. 1988.

Other specimens. These were examined live in the field and released or disposed of (18: 215-515 mm), as for lectotype, paralectotypes and other material.

Diagnosis. A species of freshwater cod, Maccullochella, differing from $M . p$. peelii by having longer pelvic fins, larger orbit length, larger and morphologically distinct sagittal otoliths, and distinctive colouration, from $M$. p. mariensis by the combination of a narrower caudal peduncle, shorter post-orbital head length, larger orbit, shorter inter-orbital width, more scale rows below the lateral line, longer fifth/sixth dorsal spine, and greater extension of the first anal pterygiophore towards the vertebral column, and from $M$. macquariensis by having a concave head profile, protruding lower jaw, 15 precaudal vertebrae, greater extension of the first anal pterygiophore towards the vertebral column and distinctive colouration.

Description. Details of morphometrics of the lectotype, paralectotypes and other material and specimens are given in Table 10.

Dorsal fin XII, 14 (X-XII, 13-16); anal fin III, 12 (III, 11-12); pectoral fin rays 17 (16-19); pelvic fin I, 5; caudal fin rays 18 (17-19); predorsal bones 2 (2-3); precaudal vertebrae 15 (15); caudal vertebrae 20 (20).

Large, elongate, deep-bodied fish; slightly compressed. Depth from dorsal origin to base pelvic fin 28.3 (26.0-
$30.3) \%$ SL. Body dorsal profile convex, highest above pectoral base. Caudal peduncle elongated, 19.8 (19.8$24.8) \%$ SL.

Head broad, width 62.1 (46.0-66.2)\% HL; moderately compressed; profile distinctly concave. Lower jaw protruding beyond upper; mouth large, gape extending to posterior border of eye. Eyes moderately large, dorsolateral; orbit length 14.3 (12.0-19.0)\% HL. Irregular rows of villiform, curved teeth in jaws, on vomer and palantines. Operculum with fleshy margin; 2 spines, lower spine largest. Edge of preoperculum smooth.

Lateral line distinct, following dorsal profile, extending to base of caudal fin; 70 (65-82) scales in lateral line. Body covered by small scales, mostly ctenoid; cheeks and opercular scaled, snout naked.

Pelvic fin inserted in advance of pectoral base; first ray elongated into 2 filaments, second long, tapering to fine tip; pelvic fin 17.9 (16.6-21.0)\% SL. Pectoral fin large, 16.7 (14.2-19.0)\% SL; upper rays longest. Dorsal fin origin posterior to pectoral and pelvic bases. Dorsal spines strong, fifth-sixth longest 10.8 (8.5-13.0)\% SL; soft dorsal fin rounded. Anal fin opposite soft dorsal, rounded; second spine largest. Caudal fin large, rounded.

Colour in life and in alcohol. In life yellow-green to golden with black to very dark green, heavily reticulated mottling on dorsal surface, head and sides, extending onto ventral surface in some specimens. Ventral surface of head and body dark grey; becoming grey-white when in turbid water (Fig.4). Dorsal, pectoral, caudal and anal fins clearish to very dark grey-green with mottling on their bases. Thin pale-grey to whitish margins sometimes present on soft dorsal, anal and caudal fins. Pelvic fin colourless, translucent; filaments white.

In alcohol, grey dorsally with black to dark grey heavily reticulated mottling on dorsal surface, head and sides; ventral surface grey and brownish. Fins dark to grey; pelvic fin white.

Species can attain a large size and cod of 22.7 to 27.3 $\mathrm{kg}$ were frequently caught in the Clarence system (Wilcox, 1863); largest specimen reported $41 \mathrm{~kg}$ from Koreelah Creek in 1921 (K. Murphy, personal communication).

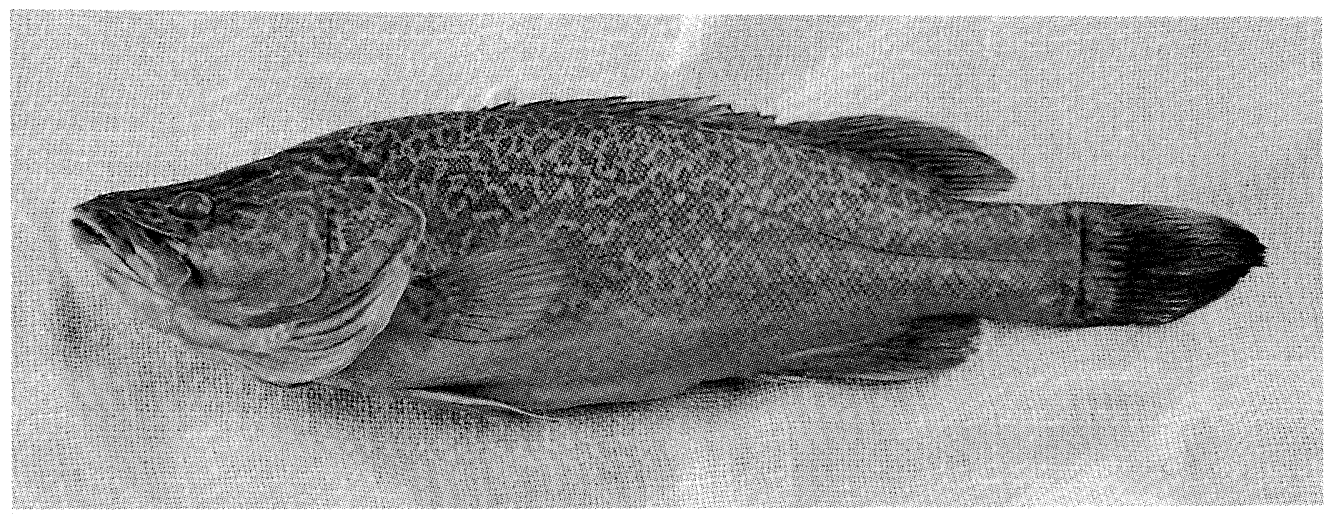

Fig.7. Maccullochella ikei. Lectotype (AMS I.31090-001), $410 \mathrm{~mm}$ SL (photograph, Kevin Clark). 
Etymology. Named ikei after the author's late grandfather, Isaac (Ike) Morgan Rowland, who was a great admirer and angler of Australian native inland fishes, in particular Murray cod.

Remarks. No types were listed in the original species description (Rowland, 1986). The type series includes all those specimens from which data were taken as listed in the unpublished thesis of Rowland (1985); the lectotype and paralectotypes are the remaining extant specimens from that syntypic series. Other material includes the specimens collected since 1985.

The population of cod in the Mary system is morphologically and genetically distinct from the other species of Maccullochella. The data suggest that this population is more similar to $M$. p. peelii than $M$. ikei, and pending breeding studies and further investigation of the evolutionary relationships within Maccullochella, is here described as a subspecies of M. peelii.

\section{Maccullochella peelii mariensis n.subsp.}

\section{Mary River cod}

Fig.4

Oligorus macquariensis.-Ogilby, 1893: 19 (in part, Mary River).-Ogilby, 1895: 71, 72 (in part, Mary River).-McCulloch \& Whitley, 1925: 102 (in part, Mary River).

Maccullochella macquariensis.-Whitley, 1937: 128 (in part Mary River).-Roughley, 1968: 133 (in part, Mary River).Lake, 1971: 33 (in part, Mary River).-Grant, 1982: 785 (in part, Mary and Dawson Rivers).-Grant, 1987: 435 (in part, Mary and Dawson Rivers).

Maccullochella peeli.-Berra \& Weatherley, 1972: 60 (in part, Mary River).-Lake, 1978: 49 (in part Mary River).Llewellyn \& MacDonald, 1980: 143 (in part, Mary and Dawson Rivers).

Maccullochella sp.-Merrick \& Schmida, 1984: 202 (Mary River system).-Harris, 1987: 9, 39 (Mary River).-Rowland, 1988c: 171 (Mary River system).-Allen, 1989: 142 (Mary River).-Ingram et al., 1990: 179, 180 (Mary River system).Pollard et al., 1990: 74 (Mary River).

Type material. HolOTYPE, QM I27994, $382 \mathrm{~mm}$, female, Queensland, Tinana Creek, Bungawatta Station (25\%48'S $152^{\circ} 42^{\prime} \mathrm{E}$ ), clay, mud and timber to $3 \mathrm{~m}$, angled, R. Cockbain, 9 Feb. 1984. PARATYPES, QM I27995, $476 \mathrm{~mm}$, female,

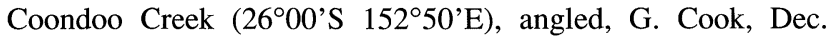
1983; QM I27996, $555 \mathrm{~mm}$, male, Coondoo Creek $\left(26^{\circ} 00^{\prime} \mathrm{S}\right.$ 152 50 'E), gill net, S. Rowland, 7 Feb. 1984; QM I27997, $417 \mathrm{~mm}$, female, same locality as preceding, gill net, S. Rowland, 8 Feb. 1984; QM I27998, 235 mm, immature, Sixmile Creek, $10 \mathrm{~km}$ upstream of junction with Mary River
(26 $\left.16^{\prime} \mathrm{S} 152^{\circ} 45^{\prime} \mathrm{E}\right)$, angled, C. Graham, 8 Feb. 1984; AMS I.32345-001, $440 \mathrm{~mm}$, female, same data as QM I27997; AMS I.32346-001, $387 \mathrm{~mm}$, male, Six-mile Creek, same locality as QM I27998 angled, J. Rowland, 9 Feb. 1984; AMS I.32347$001,464 \mathrm{~mm}$, female, same locality as preceding, angled, C. Graham, 9 Feb. 1984.

Diagnosis. A subspecies of Maccullochella peelii distinguished from the nominal subspecies by the combination of longer pelvic fins, deeper and shorter caudal peduncle, shorter extension of first anal pterygiophore towards vertebral column, larger sagittal otoliths and distinctive colouration, from $M$. ikei by the combination of deeper caudal peduncle, greater postorbital head length, smaller orbit, larger interorbital width, fewer scale rows below lateral line, shorter fifthsixth dorsal spine and shorter extension of the first anal pterygiophore, and from $M$. macquariensis by having concave head profile, protruding lower jaw, 15 precaudal vertebrae and distinctive colouration.

Description. Details of morphometrics are given in Table 7. Similar general shape to $M$. p. peelii and $M$. ikei but with following details.

Dorsal fin XI, 15; anal fin III, 13 (III, 12-13); pectoral fin rays 18 (19-20); pelvic fin I, 5; caudal fin rays 18 (16-18); predorsal bones 2 (2-3); precaudal vertebrae 15 ; caudal vertebrae 19 (19-20).

Depth from dorsal origin to base pelvic fin 31.6 (28.3-33.6)\% SL. Caudal peduncle elongated 19.3 $(19.0-21.4) \%$ SL and relatively deep 13.5 (12.3-14.2)\% SL.

Head width 65.0 (47.8-64.6)\% HL; orbit length 13.9 (10.0-13.8)\% HL.

Lateral line scales 67 (68-74); pelvic fin 18.4 (16.419.8)\% SL; pectoral fin 18.3 (16.5-19.3)\% SL; fifth-sixth dorsal spine longest $9.3(6.1-9.8) \%$ SL.

Colour in life and alcohol. In life yellowish to pale green with dark heavily reticulated mottling on dorsal surface, head and sides, extending onto ventral surface in some specimens. Ventral surface of head and body grey-green to whitish. Dorsal, pectoral, caudal and anal fins clearish to dark with grey-green mottling on their bases. Thin whitish margins on soft dorsal, anal and caudal fins. Pelvic fin colourless to whitish; filaments white.

In alcohol, grey dorsally and grey-brown on sides with dark reticulated mottling on dorsal surface, head and sides; ventral surface grey-brown. Fins dark to greybrown; pelvic fin white.

Subspecies can attain a large size and reported to grow to $23.5 \mathrm{~kg}$ (Merrick \& Schmida, 1984).

Etymology. Named mariensis after the Mary River in which the new subspecies is endemic. 


\section{Key to the Species of Maccullochella in South-eastern Australia}

1. Head profile straight. Upper jaw overhangs lower jaw. Blue-grey dorsally with speckled pattern of dark grey to black spots and small bars dorsally and laterally. Precaudal vertebrae 14 Maccullochella macquariensis

_ Head profile concave. Jaws equal or lower jaw protruding. Distinct mottled pattern dorsally and laterally. Precaudal vertebrae 15

2. Cream to olive to yellow-green with pale to dark green reticulated mottling dorsally and laterally sometimes with small dark spots between reticulation; ventral surface white to creamy-white. Whitish, relatively short pelvic fin $13.2-16.4 \%$ standard length. Orbit length 9.7-12.9\% head length. Anal rays 12-15. Otolith with prominent antirostrum; otolith length 2.5$2.9 \%$ total length Maccullochella peelii peelii

Pale green to yellow-green to golden with black to very dark green, heavily reticulated mottling dorsally and laterally, sometimes extending onto ventral surface; ventral surface dark grey to whitish. Clear, relatively long pelvic fin 16.4-20.7\% standard length. Otolith with small antirostrum; otolith length $2.9-3.5 \%$ total length......

3. Depth caudal peduncle $12.3-14.2 \%$ standard length. Orbit length $10.0-13.8 \%$ head length. Interorbital width 25.1-30.4\% head length. Scale rows below lateral line 30-34. Fifth/sixth dorsal spine $6.1-9.8 \%$ standard length. Anal rays 12-13. First anal pterygiophore length $79-86 \%$ distance from its base to first caudal vertebra. Otolith length $2.9-3.3 \%$ total length

Maccullochella peelii mariensis

- Depth caudal peduncle 10.7-12.5\% standard length. Orbit length $12.0-19.0 \%$ head length. Interorbital width 20.8-27.5\% head length. Scale rows below lateral line 32-52. Fifth/sixth dorsal spine $8.5-13.0 \%$ standard length. Anal rays 11-12. First anal pterygiophore length $89-97 \%$ distance from its base to first caudal vertebra. Otolith length $3.2-3.5 \%$ total length. Maccullochella ikei

\section{Discussion}

Although the relationship between allopatric populations can be difficult to determine, the technique of electrophoresis enables a quantitative analysis of genetic divergence, and when coupled with morphological techniques, information on taxonomic, and phylogenetic relationships between populations is maximised (Hillis, 1987). The values of the coefficients of genetic identity and genetic distance between $M$. $p$. peelii and $M$. ikei $(\mathrm{I}=0.72 ; \mathrm{D}=0.33)$ and between $M$. ikei and $M$. p. mariensis $(0.73 ; 0.32)$ are consistent with values previously reported between congeneric species of fishes (Avise, 1974; Ayala, 1975; Shaklee \& Tamaru, 1981; Shaklee et al., 1982). The species-specific banding patterns of $M p i-1, I d h-2$, Iddh-1, Gpi-A and G3pdh-1, liver esterases, and the muscle general protein, as well as the morphometric differences and the abnormalities and inviability of hybrid larvae provide strong evidence of the divergence and evolution of reproductive isolation between cod from the Murray-Darling and Clarence systems.

The 'subspecies' taxon is generally used to arbitrarily identify geographically isolated populations that have undergone some morphological and/or genetic change (Dobzhansky, 1970; Frankel \& Soulé, 1981). The cod population in the Mary system is genetically and 
morphologically distinct from both $M$. p. peelii and $M$. ikei. Although the phenotypes of muscle general protein (Fig.2) and the character length of pelvic fin suggest a closer relationship to $M$. ikei, the coefficient of genetic identity with $M$. peelii of 0.85 is in the range $(0.80$ 0.96) normally associated with subspecies of fish (Avise, 1974; Avise \& Smith, 1977; Philipp et al., 1983; Crabtree \& Buth, 1987; Leary et al., 1987). Overall, the genetic and morphometric data suggest a closer relationship to $M$. p. peelii, hence the description of cod in the Mary system as $M . p$. mariensis. The two distinct forms of cod in this system that are recognised by fishermen (Merrick \& Schmida, 1984) were not identified in the current study.

It is hypothesised that the cod of the western drainage was the ancestral stock from which founders of $M$. ikei and $M$. p. mariensis become geographically isolated. Fossil Murray cod of Miocene Age (26-7 million years ago [mya]) have been found in the Warrumbungle Mountains and Cooma regions (Hills, 1946; Taylor et al., 1980). Diatom flora associated with some of these fossils is of the type found with lower Tertiary basalts (Gill, 1970) and so ancestral Maccullochella may be up to 60-65 m y old (Rowland, 1989).

The genetic distances and the estimated times of divergence (1.7-0.8 mya) suggest that the vertical uplift associated with the formation of the Great Dividing Range (GDR) was not responsible for the geographic isolation of cod in the eastern drainage. Most of the earth movements which formed the Eastern Highlands took place before the Miocene (Ollier, 1978) and the GDR assumed its present gross character early in the Cainozoic Era which commenced 65 mya (Jones \& Veevers, 1980). The westward migration of the dividing range has resulted in complex, large-scale stream capture and short, steep coastal rivers have been successively capturing the headwaters of westerly-flowing streams (Herbert, 1980). The founder populations of $M$. ikei and $M$. p. mariensis could have become isolated in the eastern drainage, during this process of stream capture, as was first suggested by McCulloch (1914) to explain the presence of 'Murray cod' in north-eastern NSW and south-eastern Queensland. Speciation can be very rapid in small founder populations (Mayr, 1982) and the vastly different types of habitats in the coastal river systems compared to the western drainage could have contributed to rapid divergence and speciation. An alternative hypothesis is that cod have made separate invasions of Australian freshwaters from marine environments east and west of the GDR, as has been suggested for some atherinids by Crowley (1990).

Although conspecific populations have been recorded east and west of the GDR (Crowley, 1990) in other species of fish, two previous studies have also identified separate species. Crowley et al. (1986) found that the rainbowfish of the coastal systems of northern NSW and southern Queensland is Melanotaenia duboulayi, whereas $M$. fluviatilis is confined to the Murray-Darling system, and Dufty (1986) suggested that eastern and western populations of Macquarie perch
(Macquaria australasia) are separate species. The findings of these, plus the current study suggest that the GDR has played a role in the speciation of some freshwater fishes in eastern Australia. There is clearly a need to maintain the integrity of native fish faunas within drainages, particularly where there is doubt about the taxonomic and reproductive relationships between populations.

Past and present distribution and abundance of cod in the eastern drainage. Historical reports of the $1800 \mathrm{~s}$ and early 1900s indicate that large populations of cod were once present in each of the Clarence, Richmond, Brisbane and Mary systems. When the Clarence Valley was first settled in the $1830 \mathrm{~s}$, cod were plentiful in all the freshwater reaches of the Clarence River and its tributaries (Bawden, 1888) and fish up to $27.3 \mathrm{~kg}$ were frequently caught in the Clarence and Orara Rivers (Wilcox, 1863). Many of the very early settlers "lived off the land" and caught cod and other fish and native animals for food (Wilkinson, 1981). In a letter dated Grafton, 10 May 1866, the distinguished naturalist John MacGillivray wrote of catching 25 cod up to $22.7 \mathrm{~kg}$ during a trip to the Wymboida [sic] River (Beaton, 1868). Early settlers who were mainly cedar cutters, found that cod up to $27.3 \mathrm{~kg}$ were plentiful in the Richmond River and many of its tributaries (Bundock, 1898; S. King, R. Russ, personal communication). In 1824, the explorers John Oxley and Allan Cunningham recognised a fish that had been caught from the Brisbane system by an old Aborigine, as the cod found in the western rivers (McMinn, 1970). There were numerous reports about the relative abundance of what were presumed to be Murray cod in the upper Stanley River, a major tributary of the Brisbane River, during the early 1900s (Stephenson, 1953) and cod were so plentiful in the Brisbane and Mary systems during the early 1900 s that some settlers used them as pig feed (J. Winkel, personal communication).

There has been a dramatic reduction in the distribution and abundance of cod in the eastern drainage and cod were probably extinct in the Brisbane and Richmond systems by the end of the 1930s. Only a few cod were reported from the Stanley River in the 1940s (Stephenson, 1953) and there has not been an authenticated report of cod from any location in the Brisbane system since that time (S.H. Midgley, R. McKay, personal communication). A marked decline of cod in the Richmond River occurred after 1926 when the north coast railway, which closely follows the river, was constructed north of Casino. Elderly, local residents claim that the river was extensively dynamited during the construction of the railway (B. Wilson, personal communication), and this, plus several very large fish kills involving many cod during heavy flooding in the 1920s and 1930s (D. Machin, S. King, personal communication) were probably the major factors in the demise of cod in this system. The last authenticated capture of a cod from the Richmond system was in 1971 (J. Bell, personal communication).

There has been a decline in the number of cod in 
the Mary system since the early 1900s (S.H. Midgley, J. Winkel, K. Passlow, personal communication) and the population in this system is now restricted mainly to Sixmile, Tinana, Coondoo, Widgee, Station and Oby Oby Creeks. Cod are not common in the Mary River where the clearing of timber from the river and its banks for agricultural development has led to extensive siltation and loss of in-stream cover (S.H. Midgley, personal communication).

Cod disappeared from much of the Clarence system after a number of massive fish kills during the late 1920 s and the 1930s. Long dry periods, followed by extensive bushfires and then heavy summer rains preceded some of the fish kills (S. Adams, K. Murphy, F. Winters, personal communication). Such conditions have been reported to cause a deterioration of water quality, including a marked depletion of dissolved oxygen, and increased turbidity, concentration of suspended solids, electrical conductivity and nutrient levels in some Australian rivers (Chessman, 1986). In addition, releases of contaminated water from the tailings dams at gold and tin mines are also thought to have caused the death of cod and other freshwater fish in parts of the Clarence system (F. Winters, personal communication).

Cod are now very rare or absent in the major northern tributaries of the system, the Clarence, Rocky and Cataract Rivers and they are no longer found in the Orara River, where they were once very common (Wilcox, 1863). The north coast railway, in part, closely follows the Orara River from Coffs Harbour to Grafton and dynamiting may have also been responsible for the rapid decline of cod in this river. Parts of the catchments of these rivers have undergone some agricultural development and this may have contributed to a loss of cod habitat. Since the late 1960s small numbers of cod (usually less than $5 \mathrm{~kg}$ ) have been caught

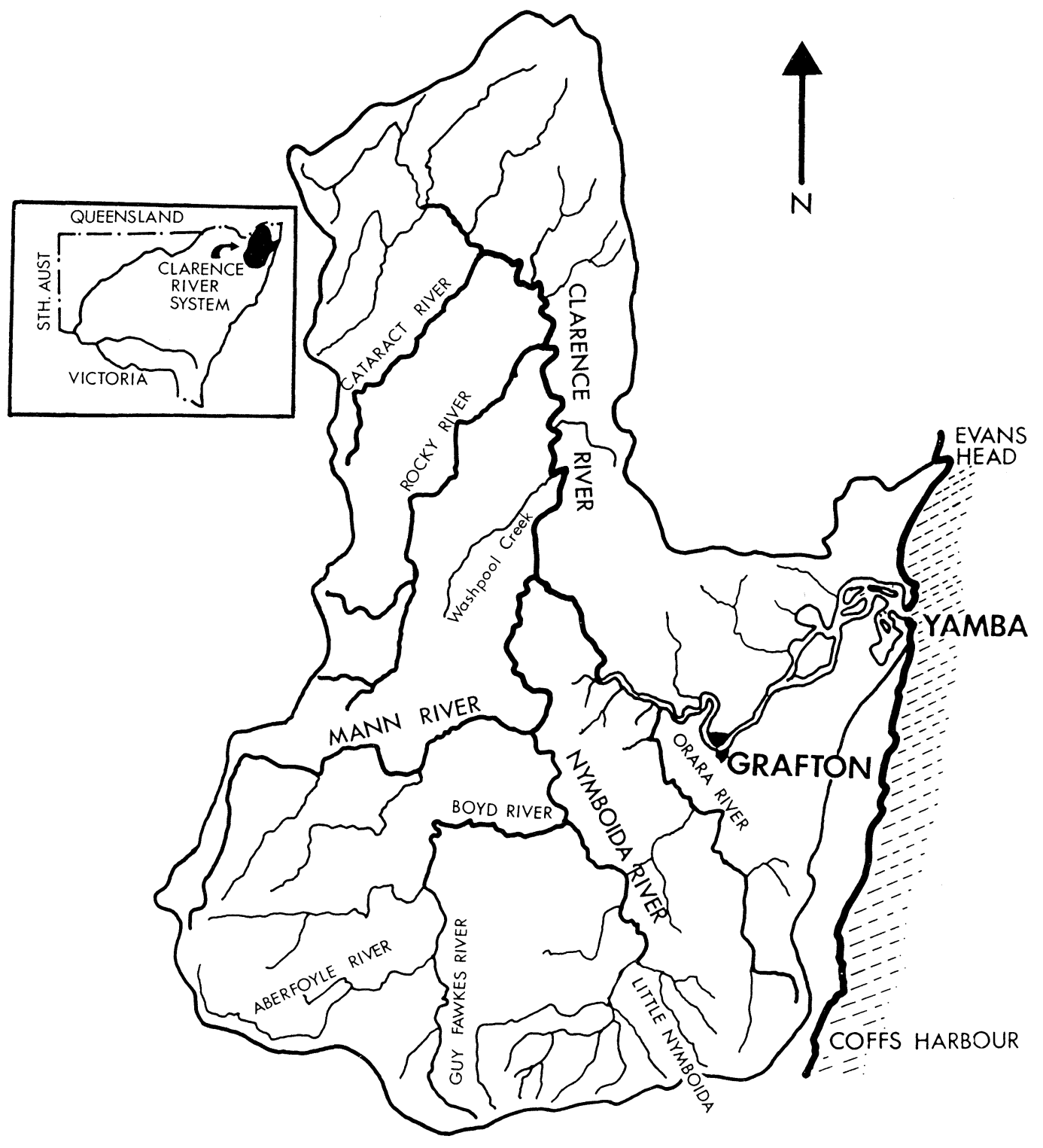

Fig.8. The Clarence River system, NSW. 
only from tributaries such as the Nymboida, Little Nymboida, Boyd and Mann Rivers (Fig.8), where some pristine habitat still exists.

Maccullochella ikei and M. p. mariensis, like other species of Maccullochella, are large, long-lived, slowgrowing species, with relatively low fecundity and a long generation period (Rowland, 1985). An extended age distribution in such fishes represents an evolutionary adaptation by which potentially high larval mortality in unfavourable breeding seasons is compensated for by repeated annual spawnings over the life span of individuals (Giesel, 1976; May, 1976). It is possible that $M$. ikei and $M$. p. mariensis have lost this advantage and that the intrinsic biology of these species has prevented their recovery from the low population levels caused by the fish kills and other factors. In addition, these species are potentially threatened by overfishing, pollution, habitat destruction or degradation, including the deterioration of water quality, the introduction of fishes not native to the eastern drainage (including possible hybridisation with hatchery-reared Murray cod), disease, the loss of genetic variability, and inbreeding. Small, isolated populations are extremely susceptible to extinction (Frankel \& Soulé, 1981).

Maccullochella ikei, an endangered species. The eastern freshwater cod is now classified as endangered (Harris, 1987; Ingram et al., 1990). In an effort to conserve $M$. ikei, there is a prohibition on the capture of freshwater cod, Maccullochella spp. from waters north of the Macleay River to the Queensland border, and the Eastern Freshwater Fish Research Hatchery has been constructed at Grafton so that techniques for the artificial breeding of $M$. ikei can be developed. Guidelines for the genetically-sound production and stocking of Australia's endangered and threatened fishes have been established (Rowland \& Barlow, 1988) and the successful restocking of the Richmond and Clarence Rivers systems with hatchery-reared fry will reduce the vulnerability of $M$. ikei to the factors which cause extinction.

ACKNOWLEDGMENTS. I thank the following for assistance in collecting specimens; Ron Cockbain, Colin Graham, Norm Rowland, Jack Rowland, Kevin Clark, Robert Lockwood, Howie Davison, Max Graham, Rob Smith, Gordon Winter, Ray Mepham, Kevin Mepham and members of the Bingara Anglers Club. Gerald Cook, Len Green and Jim Winkel provided specimens and information on cod in the Mary system. In addition, Rolly McKay, Hamar Midgley, Kathleen Passlow, Sid Adams, Fred Winters, David Machin, Keith Murphy, S. King, B. Russ, B. Wilson, S. Gilbert and Jim Bell and members of the Kyogle Acclimatisation Society provided historical information on cod in the eastern drainage.

Technical assistance was provided by Peter Selosse, Ken Bock, Frank Prokop, Kevin Clark and George Stewart. Drs David Briscoe (Macquarie University) and James Shaklee (CSIRO) provided laboratory facilities for electrophoresis, and I thank John Stevens and Dr Clive Keenan for assistance. Denis Reid conducted the canonical variates analysis. I thank
Dr John Paxton for allowing me access to the records, collections of fishes and the x-ray facilities at the Australian Museum, and Mark McGrouther for assistance at the museum. I sincerely thank Rolly McKay, Fred Reynolds and Drs James Shaklee, Jean Joss and David Pollard and, in particular Dr John Paxton, for their advice during the study and comments on drafts of this paper. I thank David Rodgers and Geoff Biddle for preparing the photographs, Gunther Schmida for providing the photographs of the Mary River cod and the trout cod, Peter Williamson the map, and Barbara Butler and Kerri Gibbins for typing draft manuscripts.

\section{References}

Allen, G.R., 1989. Freshwater Fishes of Australia. Tropical Fish Hobbyist, Brookvale.

Anderson, H.K., 1916. Note on inland fisheries and fishery investigations in New South Wales during 1915. Pp. 1633. In Fisheries. Report on the Fisheries of New South Wales for the year 1915. Government Printer, Sydney.

Angas, G.F., 1860. Donations to the Australian Museum, received during the year 1859, p.5. In Australian Museum. Report of the Trustees of the Australian Museum, for the year ending 31 December, 1859. Government Printer, Sydney.

Anon., 1859. Donations to the Australian Museum during April 1859. Sydney Morning Herald 7 May, p.5.

Avise, J.C., 1974. Systematic value of electrophoretic data. Systematic Zoologist 23: 465-481.

Avise J.C. \& G.B. Kitto, 1973. Phosphoglucose isomerase gene duplication in the body fishes: an evolutionary history. Biochemical Genetics 8: 113-132.

Avise, J.C. \& M.H. Smith, 1977. Gene frequency comparisons between sunfish (Centrarchidae) populations at various stages of evolutionary divergence. Systematic Zoologist 26: 319-334.

Ayala, F.J., 1975. Genetic differentiation during the speciation process. Evolutionary Biology 8: 1-78.

Bawden, T., 1888. Personal recollections of early days in the Clarence district the stations and all about them. Pp. 88182. In The Bawden Lectures. June 1886, July 1886, August 1888. The First Fifty Years of Settlement on the Clarence. Records in the Clarence River Historical Society with notes by Mr R.C. Law.

Beaton, P.C., 1868. A martyr to science. Good Words July 1868: 425-429.

Bennett, G., 1864. Notes on the River Cod and perch of the colonists. In Third Annual Report of the Acclimatisation Society of NSW.

Berra, T.M. \& A.H. Weatherley, 1972. A systematic study of the Australian freshwater serranid fish genus Maccullochella. Copeia 1972(1): 53-64.

Bundock, M., 1898. Notes of the Richmond River blacks. Manuscript Mitchell Library Sydney.

Chessman, B.C., 1986. Impact of the 1983 wildfires on river water quality in east Gippsland, Victoria. Australian Journal of Marine and Freshwater Research 37: 399-420.

Crabtree, C.B. \& D.C. Buth, 1987. Biochemical systematics of the catostomid genus Catostomus: assessment of $C$. clarkii, $C$. plebeius and $C$. discobolus including the Zuni sucker, C. d. yarrowi. Copeia 1987 (4): 843-854.

Crowley, L.E.L.M., 1990. Biogeography of the endemic freshwater fish Craterocephalus (Family Atherinidae). 
Memoirs of the Queensland Museum 28(1): 89-98.

Crowley, L.E.L.M., W. Ivantsoff \& G.R. Allen, 1986. Taxonomic position of two crimson-spotted rainbowfish, Melanotaenia duboulayi and Melanotaenia fluviatilis (Pisces: Melanotaeniidae), from eastern Australia, with special reference to their early life-history stages. Australian Journal of Marine and Freshwater Research 37: 385-398.

Dobzhansky, T., 1970. Genetics of the Evolutionary Process. Columbia University Press, New York, 505 pp.

Dufty, S., 1986. Genetic and morphological divergence between populations of Macquarie perch (Macquaria australasica) east and west of the Great Dividing Range. Honours Thesis, University of New South Wales.

Engel, W., J. Faust \& U. Wolf, 1971. Isoenzyme polymorphism of the sorbitol dehydrogenase and the NADP-dependent isocitrate dehydrogenases in the fish family Cyprinidae. Animal Blood Groups and Biochemical Genetics 2: 127133.

Frankel, O.H. \& M.E. Soulé, 1981. Conservation and Evolution. Cambridge University Press, Sydney, 327 pp.

Giesel, J.T., 1976. Reproductive strategies as adaptations to life in temporally heterogeneous environments. Annual Review of Ecological Systematics 7: 57-79.

Gill, E.D., 1970. Rivers of History. Australian Broadcasting Commission, Sydney.

Grant, E.M., 1982. Guide to Fishes. Department of Harbours and Marine, Brisbane.

Grant, E.M., 1987. Fishes of Australia. E.M. Grant, Scarborough.

Harris, J.H., 1987 (ed.). Proceedings of the Conference on Australian Threatened Fishes. Department of Agriculture, New South Wales, Sydney, $70 \mathrm{pp}$.

Herbert, C., 1980. A tectonic origin for southeast Australian streams. Abstract from Symposium on Cainozoic Evolution of Continental Southeastern Australia. Bureau of Mineral Resources, Geology and Geophysics, Canberra.

Hill, E., 1864. Fishes. In Third Annual Report of the Acclimatisation Society of NSW.

Hillis, D.M., 1987. Molecular versus morphological approaches to systematics. Annual Review of Ecological Systematics 18: 23-42.

Hills, E.S., 1946. Fossil Murray cod (Maccullochella macquariensis) from diatomaceous earths in New South Wales. Records of the Australian Museum 21: 380-382.

Hoser, R.T., 1991. Endangered Animals of Australia. Pierson \& Co., Sydney, $240 \mathrm{pp}$.

Hubbs, C.L. \& K.E. Lagler, 1974. Fishes of the Great Lakes Region. University Michigan Press, Ann Arbor, USA, 135 pp.

Ingram, B.A., C.G. Barlow, J.J. Burchmore, G.J. Gooley, S.J. Rowland \& A.C. Sanger, 1990. Threatened native freshwater fishes in Australia - some case histories. Journal of Fish Biology 37(Supplement A): 175-182.

Jones, J.G. \& J.J. Veevers, 1980. History of the southeast Australian highlands. Abstract from Symposium on Cainozoic Evolution of Continental Southeastern Australia. Bureau of Mineral Resources, Geology and Geophysics, Canberra.

Keenan, C.P. \& J.B. Shaklee, 1985. Electrophoretic identification of raw and cooked fish fillets and other marine products. Food Technology in Australia 37(3): 117-128.

Lake, J.S., 1959. The freshwater fishes of New South Wales. State Fisheries Research Bulletin Number 5: 1-20.

Lake, J.S., 1967. Freshwater fish of the Murray-Darling River system. NSW State Fisheries Research Bulletin No.7: 148.

Lake, J.S., 1971. Freshwater Fishes and Rivers of Australia.
Thomas Nelson, Sydney, $61 \mathrm{pp}$.

Lake, J.S., 1978. Australian Freshwater Fishes; an Illustrated Field Guide. Thomas Nelson, West Melbourne, pp.

Leary, R.F., R.W. Allendorf, S.R. Phelps \& K.L. Knudsen, 1987. Genetic divergence and identification of seven cutthroat trout subspecies and rainbow trout. Transactions of the American Fisheries Society 116: 580-587.

Llewellyn, L.C., 1983. The distribution of fish in New South Wales. Australian Society for Limnology Special Publication No.7: 1-70.

Llewellyn, L.C. \& M.C. MacDonald, 1980. Family Percichthyidae. Pp. 142-149. In R.M. McDowall (ed.). Freshwater Fishes of South-eastern Australia. Reed, Sydney.

MacDonald, M.C., 1978. Morphological and biochemical systematics of Australian freshwater and estuarine percichthyid fishes. Australian Journal of Marine and Freshwater Research 29: 667-698.

Macleay, W., 1887. Notes and exhibits. Proceedings of the Linnean Society of New South Wales II(IV): 981-982.

Macleay, W., J.C. Cox, W.B. Dalley, H.C. Dangar, R. Driver, J.S. Farnell, R. Hill, F. Hixson, T. Holt, A. Oliver, E.P. Ramsay, C.C. Skarratt, G. Thornton \& G.F. Want, 1880. Fisheries Enquiry Commission. Report of the Royal Commission, to Enquire into and Report upon the Actual State and Prospect of the Fisheries of this Colony. Government Printer, Sydney.

May, R.M., 1976. Models for single populations. Pp. 4-25. In R.M. May (ed.). Theoretical Ecology Principles and Applications. W.B. Saunders Co., Philadelphia.

Mayr, E., 1982. Speciation and macroevolution. Evolution 36(6): 1119-1132.

McCulloch, A.R., 1914. The fishes of New South Wales. Pp. 322-329. In British Association for the Advancement of Science. Handbook for New South Wales. Edward Lee \& Co., Sydney.

McCulloch, A.R., 1922. Checklist of the Fishes and Fish-like Animals of New South Wales. Royal Zoological Society of New South Wales.

McCulloch, A.R., 1927. The Fishes and Fish-like Animals of New South Wales. Royal Zoological Society of New South Wales.

McCulloch, A.R. \& G.P. Whitley, 1925. A list of the fishes recorded from Queensland waters. Memoir of the Queensland Museum VIII(II): 125-182.

McMinn, W.G., 1970. Allan Cunningham Botanist and Explorer. University Press, Melbourne.

Merrick J.R. \& G.E. Schmida, 1984. Australian Freshwater Fishes. Biology and Management. J.R. Merrick, Macquarie University, North Ryde, 409 pp.

Nei, M., 1972. Genetic distance between populations. American Naturalist 106: 283-292.

Nei, M., 1975. Molecular Population Genetics and Evolution. North Holland, Amsterdam.

O'Connor, D., 1897. Fish acclimatisation in Queensland. Proceedings of the Royal Society of Queensland 12: 108110.

Ogilby, J.D., 1886. Catalogue of the Fishes of New South Wales with their Principal Synonyms. Government Printer, Sydney.

Ogilby, J.D., 1893. Edible Fishes and Crustaceans of New South Wales. Government Printer, Sydney.

Ogilby, J.D., 1895. Freshwater fishes of New South Wales. Natural Science VI(35): 71-72.

Ollier, D.C., 1978. Tectonics and geomorphology of the Eastern Highlands. Pp. 5-47. In J.L. Davies \& M.A.J. Williams (eds). Landform Evolution in Australasia. Australian National 
University Press, Canberra.

Philipp, D.P., W.F. Childers \& G.S. Whitt, 1983. A biochemical genetic evaluation of the northern and Florida subspecies of largemouth bass. Transactions of the American Fisheries Society 112(1): 1-20.

Pollard, D.A., B.A. Ingram, J.H. Harris \& L.F. Reynolds, 1990. Threatened fishes in Australia - an overview. Journal of Fish Biology 37(Supplement A): 67-78.

Pollard, D.A., L.C. Llewellyn \& R.D.J. Tilzey, 1980. Management of freshwater fish and fisheries. Pp. 227-270. In W.D. Williams (ed.). An Ecological Basis for Water Resource Management. Australian National University Press, Canberra.

Reyment, R.A., R.E. Blackith \& N.A. Campbell, 1984. Multivariate Morphometrics. Academic Press, Sydney.

Roughley, T.C., 1968. Fish and Fisheries of Australia. Halstead Press, Sydney.

Rowland, S.J., 1985. Aspects of the Biology and Artificial Breeding of the Murray cod, Maccullochella peeli and the Eastern Freshwater Cod, M. ikei sp. nov. Ph.D. Thesis, Macquarie University, $253 \mathrm{pp}$.

Rowland, S.J., 1986. Identification and conservation of the eastern freshwater cod. Pp. 16-17. In Biennial Report, July 1983-June 1985, Agricultural Research and Advisory Station, Grafton. Department of Agriculture, New South Wales.

Rowland, S.J., 1988a. Hormone-induced spawning of the Australian freshwater fish Murray Cod, Maccullochella peeli (Mitchell) (Percichthyidae). Aquaculture 70: 371-389.

Rowland, S.J., 1988b. Eastern freshwater cod (Maccullochella ikei): identification, status conservation and potential threats. Pp. 18-23. In S.J. Rowland \& R. Barlow (eds). Proceedings of a Fish Genetics Workshop. NSW Agriculture \& Fisheries, Haymarket.

Rowland, S.J., 1988c. Native freshwater recreational fisheries of eastern Australia. Pp. 166-174. In R. Allan (ed.). Go Fish Australia. Australian Broadcasting Corporation, Crows Nest.

Rowland, S.J., 1989. Aspects of the history and fishery of the Murray cod, Maccullochella peeli (Mitchell) (Percichthyidae). Proceedings of the Linnean Society of New South Wales 111(3): 201-213.

Rowland, S.J. \& R. Barlow, 1988 (Editors). Proceedings of a Fish Genetics Workshop. NSW Agriculture \& Fisheries, $56 \mathrm{pp}$.
Shaklee, J.B., 1983. Mannosephosphate isomerase in the Hawaiian spiny lobster Panulirus marginatus: a polymorphic, sex-linked locus useful in investigating embryonic and larval sex ratios. Marine Biology 73: 193-201.

Shaklee, J.B., M.J. Champion \& G.S. Whitt, 1974. Developmental genetics of teleosts: a biochemical analysis of lake chubsucker ontogeny. Developmental Biology 38: 356-382.

Shaklee, J.B. \& C.P. Keenan, 1986. A Practical Laboratory Guide to the Techniques and Methodology of Electrophoresis and its Application to Fish Fillet Identification. Report 177, CSIRO Marine Laboratories, Hobart, 59 pp.

Shaklee, J.B. \& C.S. Tamaru, 1981. Biochemical and morphological evolution of Hawaiian bonefishes (Albula). Systematic Zoologist 30(2): 125-146.

Shaklee, J.B., C.S. Tamaru \& R.S. Waples, 1982. Speciation and evolution of marine fishes studies by the electrophoretic analysis of proteins. Pacific Science 36(2): 141-157.

Shaw, C.R. \& R. Prasad, 1970. Starch gel electrophoresis of enzymes - a compilation of recipes. Biochemical Genetics 4: 297-320.

Stephenson, W., 1953. The natural history of somerset Dam and its fishing potentialities. Queensland Harbours and Marine Ichthyological Notes 1(2): 21-47.

Taylor, G., P.H. Walker, N.O. Jones \& J. Hutka, 1980. The nature and significance of lacustrine deposits near Bunyon, N.S.W. Abstract from Symposium on Cainozoic Evolution of Continental Southeastern Australia. Bureau of Mineral Resources, Geology and Geophysics, Canberra.

Tenison-Woods, J.E., 1883. Fish and Fisheries of New South Wales. Government Printer, Sydney.

Thompson, L.G., 1893. History of the Fisheries of New South Wales. Government Printer, Sydney.

Wheat, T.E., G.S. Whitt \& W.F. Childers, 1973. Linkage relationships among six enzyme loci in interspecific sunfish hybrids. Genetics 74: 343-350.

Whitley, G.P., 1937. Further ichthyological miscellanea. Memoirs of the Queensland Museum XI(II): 113-148.

Wilcox, J.F., 1863. Murray River cod. Sydney Morning Herald 15th September, p.5.

Wilkinson, I., 1981. Forgotten Country. The Story of the Upper Clarence Gold Fields. Northern Star, Lismore, 292 pp.

Accepted June 16, 1992 
APPENDIX

Table 1. Number and standard length of cod from each sampling site.

\begin{tabular}{|c|c|c|c|}
\hline River system & Sampling sites & $\begin{array}{l}\text { No. of cod } \\
\text { sampled }\end{array}$ & $\begin{array}{l}\text { Standard length } \\
\text { range }(\mathrm{mm})\end{array}$ \\
\hline \multirow[t]{4}{*}{ Murray-Darling } & $\begin{array}{l}\text { Gwydir River (near Bingara) and } \\
\text { MacIntyre River (Elsmore) }\end{array}$ & 10 & $375-495$ \\
\hline & $\begin{array}{l}\text { Murray River (Lock 15), Edwards } \\
\text { River (Stevens Weir) and Wakool } \\
\text { River (Wakool) }\end{array}$ & 15 & $355-520$ \\
\hline & Farm dams near Narrandera & 12 & $242-510$ \\
\hline & Lake Mulwala & 8 & $530-680$ \\
\hline \multirow[t]{2}{*}{ Clarence } & $\begin{array}{l}\text { Within } 32 \mathrm{~km} \text { of the junction of } \\
\text { the Mann and Nymboida River }\end{array}$ & 18 & $212-515$ \\
\hline & as above & $14^{\mathrm{a}}$ & $305-456$ \\
\hline Mary & Six-mile, Coondoo and Tinana creeks & 9 & $235-555$ \\
\hline
\end{tabular}

a lectotype, paralectotypes and other material.

Table 2. Details of electrophoretic systems.

\begin{tabular}{|c|c|c|c|c|c|}
\hline \multirow[t]{2}{*}{ System } & \multirow[t]{2}{*}{ Medium } & \multirow[t]{2}{*}{ Buffer } & \multicolumn{3}{|c|}{ Running conditions } \\
\hline & & & $\begin{array}{l}\text { voltage } \\
\text { (V) }\end{array}$ & $\begin{array}{c}\text { current } \\
(\mathrm{mA})\end{array}$ & $\begin{array}{c}\text { time } \\
\text { (h) }\end{array}$ \\
\hline A & polyacrylamide & discontinuous $\mathrm{LiDH}^{\mathrm{a}}$ & 1500 & 40 & 3 \\
\hline B & starch & Tris maleate $(\mathrm{pH} 7.4)$ & 50 & 40 & 15.5 \\
\hline $\mathrm{C}$ & starch & as above & 60 & 50 & 6.5 \\
\hline $\mathrm{D}$ & starch & Tris borate EDTA (pH 8.6) & 100 & 25 & 19 \\
\hline $\mathrm{E}$ & starch & Lithium borate-tris citrate $(\mathrm{pH} 8.2 ; \mathrm{pH}$ 6.6) & 220 & - & 3 \\
\hline $\mathrm{F}$ & cellulose acetate & Tris borate EDTA (pH 8.6) & 200 & - & 1.5 \\
\hline
\end{tabular}

a after Keenan \& Shaklee (1985). 
Table 3. Proteins assayed, tissues examined, the number of loci found and the number of cod examined in the electrophoretic analysis. E.s. = Electrophoretic system; M.p.p. $=$ Maccullochella peelii peelii $;$ M. $i .=$ Maccullochella ikei; M.p.m. = Maccullochella peelii mariensis.

\begin{tabular}{|c|c|c|c|c|c|c|c|c|}
\hline Protein & EC No. & Abbreviation & E.s. & Tissue & $\begin{array}{l}\text { No. } \\
\text { loci }\end{array}$ & \multicolumn{3}{|c|}{ No. cod analysed } \\
\hline Phosphoglucomutase & 5.4.2.2 & PGM & $\mathrm{B}$ & Muscle & 1 & 8 & 6 & 6 \\
\hline Fumarase & 4.2.1.2 & FUM & $\mathrm{C}$ & Muscle & 1 & 8 & 6 & 6 \\
\hline Lactate dehydrogenase & 1.1.1.27 & $\mathrm{LDH}$ & $\mathrm{C}$ & Muscle & 1 & 8 & 6 & 6 \\
\hline Malate dehydrogenase & 1.1.1.37 & $\mathrm{MDH}$ & $\mathrm{C}$ & Muscle & 2 & 8 & 6 & 6 \\
\hline Aldolase & 4.1.2.13 & ALD & $\mathrm{F}$ & Liver & 1 & 5 & 5 & - \\
\hline Superoxide dismutase & 1.15.1.1 & SOD & $\mathrm{D}$ & Liver & 1 & 8 & 4 & 8 \\
\hline Aspartate aminotransferase & 2.6.1.1 & AAT & $\mathrm{D}$ & Liver & 2 & 8 & 4 & 8 \\
\hline Glutamate dehydrogenase & 1.4.1.3 & GLUDH & $\mathrm{F}$ & Liver & 1 & 5 & 5 & - \\
\hline Mannose-6-phosphate isomerase & 5.3.1.8 & MPI & B & Muscle & 1 & 13 & 12 & 6 \\
\hline Isocitrate dehydrogenase & 1.1.1.42 & IDHP & $\mathrm{B}$ & Muscle & 2 & 13 & 12 & - \\
\hline Malate dehydrogenase $\left(\mathrm{NADP}^{+}\right)$ & 1.1 .1 .40 & MDH(NADP) & $\mathrm{E} / \mathrm{F}$ & Muscle & 1 & 15 & 8 & 8 \\
\hline L-iditol dehydrogenase & 1.1.1.14 & IDDH & $\mathrm{F}$ & Liver & 2 & 11 & 11 & 6 \\
\hline Glucose-6-phosphate isomerase & 5.3.1.9 & GPI & $\mathrm{C}$ & Muscle & 2 & 13 & 11 & 6 \\
\hline Glycerol-3-phosphate dehydrogenase & 1.1.1.8 & G3PDH & $\mathrm{D} / \mathrm{E}$ & Muscle & 1 & 5 & 4 & 6 \\
\hline Glucose-6-phosphate dehydrogenase & 1.1.1.49 & G6PDH & $\mathrm{F}$ & Liver & 2 & 9 & 7 & 4 \\
\hline Esterases & 3.1.1.2 & EST & $\mathrm{B}$ & Liver & $?$ & 5 & 5 & - \\
\hline General protein & - & - & $\mathrm{A}$ & Muscle & $?$ & 12 & 5 & 8 \\
\hline
\end{tabular}

* includes specimens from each sampling site. 
Table 4. Allele frequencies at loci of diagnostic enzymes in species of Maccullochella.

\begin{tabular}{|c|c|c|c|c|}
\hline Locus & Allele & M. p. peelii & M. ikei & M. p. mariensis \\
\hline \multirow[t]{2}{*}{ Mpi-1 } & 100 & 1.00 & - & 1.00 \\
\hline & 87 & - & 1.00 & - \\
\hline Idh-1 & 100 & 1.00 & 1.00 & 1.00 \\
\hline \multirow[t]{2}{*}{ Idh-2 } & 100 & - & 1.00 & no data \\
\hline & 75 & 1.00 & - & \\
\hline \multirow[t]{2}{*}{ Iddh-1 } & 100 & 1.00 & - & 0.17 \\
\hline & 88 & - & 1.00 & 0.83 \\
\hline Iddh-2 & 100 & 1.00 & 1.00 & 1.00 \\
\hline \multirow[t]{2}{*}{ Gpi-A ${ }_{2}$} & 100 & 1.00 & - & 1.00 \\
\hline & 92 & - & 1.00 & - \\
\hline \multirow[t]{2}{*}{ G3pdh-1 } & 100 & - & 1.00 & - \\
\hline & 90 & 1.00 & - & 1.00 \\
\hline \multirow[t]{5}{*}{ G6pdh-1 } & 100 & 0.14 & 0.32 & 0.44 \\
\hline & 92 & 0.38 & 0.05 & - \\
\hline & 83 & 0.05 & 0.32 & 0.33 \\
\hline & 69 & 0.38 & - & 0.22 \\
\hline & 58 & 0.05 & 0.32 & - \\
\hline
\end{tabular}

Table 5. Coefficients of genetic identity (I) and the genetic distances (D) between species of Maccullochella.

$\begin{array}{lll}\text { Cod } & \mathrm{I} & \mathrm{D} \\ \text { M. p. peelii; M. ikei } & 0.72 & 0.33 \\ \text { M. p. peelii; M. macquariensis } & 0.79^{\mathrm{a}} & 0.24^{\mathrm{a}} \\ \text { M. p. peelii; M. p. mariensis } & 0.85 & 0.16 \\ \text { M. ikei; M. p. mariensis } & 0.73 & 0.32\end{array}$

a Data from MacDonald (1978). 
Table 6. Morphometric characters of $M$. p. peelii from Lake Mulwala.

Character

$\%$ STANDARD LENGTH

body depth I

body depth II

peduncle depth

peduncle length

predorsal length

dorsal base

anal base

pectoral fin

pelvic fin

head length

\% HEAD LENGTH

head width

snout length post-orbital length upper jaw length inter orbital width inter nare width

Range

Mean

S.D.

2.50

0.43

0.70

0.92

0.91

0.89

0.77

1.14

0.76

1.04

17.5

16.7

32.9

$31.5-35.0$

$47.0-51.9$
$27.0-28.8$
$57.5-64.6$
$43.0-46.5$
$22.8-29.4$
$22.3-24.2$

48.9

28.0

2.67

0.63

2.23

1.24

2.26

0.68

\section{3}

26.4

23.4

$4.22 * *$

0.68

$4.08 * *$

0.69

$3.53 *$

$2.92 *$

1.11

0.50

0.82

2.44

MERISTICS

\section{dorsal spines}

dorsal rays

anal rays

pectoral rays

gill rakers

lateral line scales

scale rows above

scale rows below

pyloric caecae

caudal rays

11.4

14.9

12.6

19.6

17.3

79.3

24.3

35.3

4.0

17.9

$\begin{array}{ll}0.52 & 0.94 \\ 0.64 & 2.05 \\ 0.52 & 0.31 \\ 0.52 & 1.71 \\ 0.76 & 1.95 \\ 6.38 & 3.76^{* *} \\ 1.03 & 1.21 \\ 2.50 & 0.78 \\ - & 0 \\ 0.84 & 0.57\end{array}$

$\mathrm{t}$ - Student's t-test comparison of means with $M$. p. peelii from rivers and farm dams. ** significant $\mathrm{P}<0.001$; $*$ significant $\mathrm{P}<0.01$; others not significant $\mathrm{P}>0.01$. 
Table 7. Comparison of morphometric characters between $M . p$. peelii (ex rivers and farm dams), M. ikei and M. p. mariensis.

Character

M. peelii

No. Range Mean S.D. $\mathrm{t}^{\mathrm{a}}$

\% Standard Length

body depth (I)

body depth (II)

peduncle depth

peduncle length

predorsal length

dorsal base

anal base

pectoral fin

pelvic fin

dorsal spine $(5$ th $/ 6$ th $)$

head length

$\begin{array}{llrll}22 & 27.2-31.6 & 29.1 & 1.29 & 0.30 \\ 32 & 25.3-33.8 & 28.1 & 2.08 & 0.98 \\ 37 & 10.3-13.0 & 11.4 & 0.66 & 0.39 \\ 37 & 19.8-23.3 & 21.8 & 1.00 & 0.94 \\ 36 & 36.8-42.5 & 40.3 & 1.35 & 0.04 \\ 35 & 42.4-47.9 & 45.1 & 1.29 & 3.23^{*} \\ 37 & 16.4-21.0 & 17.9 & 1.02 & 5.40^{* *} \\ 37 & 14.7-18.1 & 16.8 & 0.81 & 2.96^{*} \\ 37 & 13.2-16.4 & 14.9 & 0.86 & 13.49^{* *} \\ 37 & 6.5-12.5 & 8.7 & 1.64 & 3.33^{*} \\ 37 & 30.3-34.5 & 32.0 & 0.98 & 2.97^{*}\end{array}$

\section{\% Head Length}

\section{head width}

snout length

post-orbital length

orbit

upper jaw length

inter orbital width

inter nare width

$\begin{array}{lrlll}29 & 40.9-68.0 & 57.4 & 4.45 & 0.08 \\ 40 & 26.5-30.5 & 29.0 & 0.91 & 0.98 \\ 39 & 56.9-64.9 & 61.3 & 1.71 & 7.50^{* *} \\ 25 & 9.7-12.9 & 10.9 & 0.67 & 11.56^{* *} \\ 40 & 41.0-48.4 & 45.2 & 1.84 & 2.54 \\ 39 & 23.6-29.6 & 26.7 & 1.67 & 4.40^{* *} \\ 39 & 21.0-24.9 & 22.8 & 0.96 & 0.23\end{array}$

\section{Meristics}

dorsal spines

dorsal rays

anal rays

pectoral rays

gill rakers

lateral line scales

scale rows above

scale rows below

caudal rays

$$
\text { M. ikei }
$$

No. Range Mean S.D. $\mathbf{t}^{\mathrm{b}}$
M. p. mariensis

No. Range Mean S.D. $t^{c}$

$\mathrm{t}$ - Student's $\mathrm{t}$-test; $\mathrm{t}^{\mathrm{a}}-$ M. p. peelii vs $M$. ikei; $\mathrm{t}^{\mathrm{b}}-$ M. ikei vs $M$. p. mariensis; $\mathrm{t}^{\mathrm{c}}-$ M. p. peelii vs M. p. mariensis.

** significant $\mathrm{P}<0.001$; * significant $\mathrm{P}<0.01$; others not significant $\mathrm{P}>0.01$.

$\begin{array}{crrl}28.3-33.1 & 30.5 & 1.49 & 2.57 \\ 27.1-32.8 & 29.8 & 2.17 & 2.08 \\ 12.3-14.2 & 13.2 & 0.59 & 7.33^{* *} \\ 19.0-21.4 & 20.4 & 0.69 & 3.77^{* *} \\ 38.5-43.1 & 40.5 & 1.34 & 0.58 \\ 44.1-47.2 & 45.5 & 0.85 & 0.89 \\ 14.7-18.6 & 16.9 & 1.32 & 2.50 \\ 16.5-19.3 & 17.5 & 0.94 & 2.12 \\ 16.4-19.8 & 18.2 & 1.19 & 9.85^{* *} \\ 6.1-9.8 & 8.3 & 1.04 & 0.68 \\ 31.8-34.3 & 33.0 & 0.75 & 3.11^{*}\end{array}$

$\begin{array}{llll}47.8-64.6 & 57.6 & 5.57 & 0.12\end{array}$

$\begin{array}{llll}27.8-30.3 & 29.2 & 0.86 & 0.24\end{array}$

$\begin{array}{llll}57.8-61.5 & 59.9 & 1.12 & 2.40\end{array}$

$10.0-13.8 \quad 12.0 \quad 1.23 \quad 3.46^{*}$

$38.9-49.3 \quad 45.5 \quad 2.91 \quad 0.28$

$\begin{array}{llll}25.1-30.4 & 27.7 & 1.88 & 1.62\end{array}$

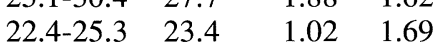


Table 8. Osteological characters of Maccullochella spp. as determined from x-rays. Number of specimens examined in parentheses.

$\begin{array}{lcccc}\text { Character } & \text { M. p. peelii } & \text { M. ikei } & \text { M. p. mariensis } & \text { M. macquariensis } \\ & (3) & (4) & (5) & (3) \\ \text { predorsal bones } & 3-4 & 2-3 & 2-3 & 2-3 \\ \text { precaudal vertebrae } & 15 & 15 & 15 & 14 \\ \text { caudal vertebrae } & 20 & 20 & 19-20 & 21 \\ \text { first anal pterygiophore } & \end{array}$

${ }^{a}$ length of first anal pterygiophore expressed as a percentage of the distance from the base of this pterygiophore to the ventral surface of the first caudal vertebra.

Table 9. Results of the cross-breeding experiment between Murray cod (MC) and eastern freshwater cod (EFC). Milt from two male Murray cod was used to fertilise the eggs stripped from the three females which ovulated.

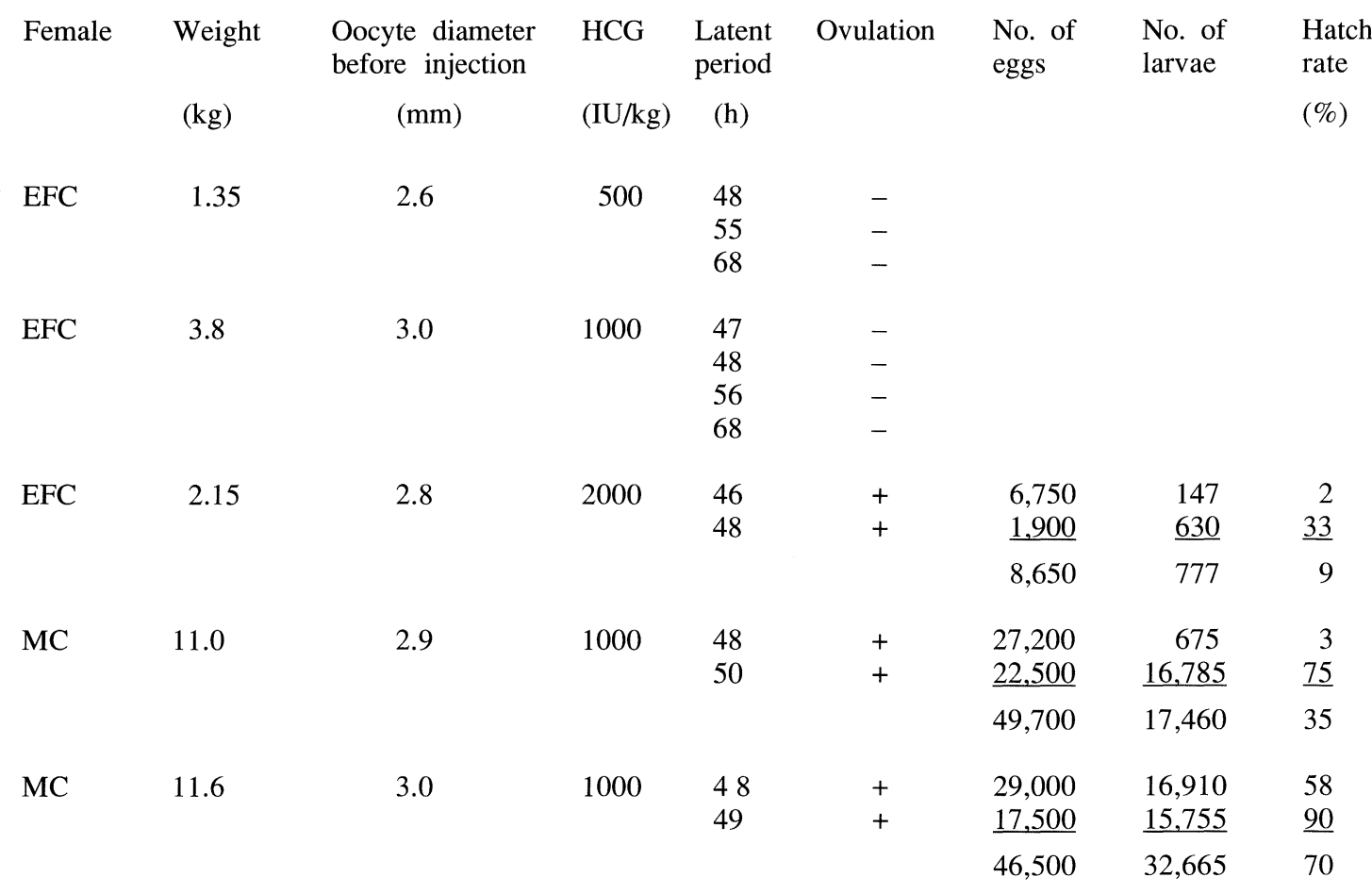


Table 10. Morphometric characters of the lectotype, paralectotypes, other material and other specimens of Maccullochella ikei.

\begin{tabular}{|c|c|c|c|c|c|}
\hline \multirow[b]{2}{*}{ Character } & \multicolumn{5}{|c|}{ Range } \\
\hline & Lectotype & $\begin{array}{l}\text { Paralectotypes } \\
\qquad(\mathrm{n}=3)\end{array}$ & $\begin{array}{l}\text { Other material } \\
\qquad(\mathrm{n}=10)\end{array}$ & $\begin{array}{l}\text { Other specimens } \\
\quad(n=18)\end{array}$ & $\begin{array}{l}\text { M. ikei } \\
(\mathrm{n}=32)\end{array}$ \\
\hline Standard length (mm) & 410 & $385-503$ & $305-456$ & $212-515$ & \\
\hline \multicolumn{6}{|l|}{$\%$ STANDARD LENGTH } \\
\hline $\begin{array}{l}\text { body depth I } \\
\text { body depth II } \\
\text { peduncle depth } \\
\text { peduncle length } \\
\text { predorsal length } \\
\text { dorsal length } \\
\text { anal base } \\
\text { pectoral fin } \\
\text { pelvic fin } \\
\text { dorsal spine }(5 \text { th } / 6 \text { th }) \\
\text { head length }\end{array}$ & $\begin{array}{l}28.3 \\
28.8 \\
11.3 \\
19.8 \\
39.9 \\
45.6 \\
17.2 \\
16.7 \\
17.9 \\
10.8 \\
32.7\end{array}$ & $\begin{array}{r}29.7-29.9 \\
28.8-31.5 \\
11.0-13.2 \\
21.5-22.2 \\
38.7-42.2 \\
41.3-45.7 \\
15.0-16.2 \\
17.4-18.1 \\
17.2-19.4 \\
9.4-10.9 \\
32.2-33.4\end{array}$ & $\begin{array}{r}26.0-30.3 \\
27.0-30.2 \\
11.0-13.2 \\
21.5-23.3 \\
39.5-42.6 \\
40.8-45.0 \\
15.2-18.1 \\
14.2-18.5 \\
16.6-19.7 \\
9.3-11.2 \\
31.9-33.7\end{array}$ & $\begin{array}{l}27.3-30.2^{*} \\
26.1-30.9^{*} \\
10.7-12.6 \\
20.0-24.8 \\
36.7-43.1 \\
40.1-47.2 \\
15.1-17.5 \\
15.8-19.0^{*} \\
16.9-21.0^{*} \\
8.5-13.0^{*} \\
31.7-36.7\end{array}$ & $\begin{array}{r}26.0-30.3 \\
26.1-31.5 \\
10.7-13.2 \\
19.8-24.8 \\
36.7-43.1 \\
40.1-47.2 \\
15.0-18.1 \\
14.2-19.0 \\
16.6-21.0 \\
8.5-13.0 \\
31.7-36.7\end{array}$ \\
\hline \multicolumn{6}{|l|}{$\%$ HEAD LENGTH } \\
\hline $\begin{array}{l}\text { head width } \\
\text { snout length } \\
\text { post-orbital length } \\
\text { orbit length } \\
\text { upper jaw length } \\
\text { inter orbital width } \\
\text { inter nare width }\end{array}$ & $\begin{array}{l}62.1 \\
29.2 \\
57.1 \\
14.3 \\
47.1 \\
23.5 \\
22.4\end{array}$ & $\begin{array}{l}59.3-65.9 \\
27.0-30.8 \\
56.2-57.5 \\
13.4-15.1 \\
47.4-47.7 \\
27.1-27.4 \\
24.3-24.6\end{array}$ & $\begin{array}{l}58.8-66.2 \\
29.2-30.9 \\
56.6-59.4 \\
12.0-15.3 \\
40.3-51.1 \\
23.5-29.1 \\
22.4-25.0\end{array}$ & $\begin{array}{l}46.0-63.5^{*} \\
27.9-30.6 \\
54.7-59.7 \\
12.8-19.0 \\
42.8-48.9 \\
20.8-27.5 \\
21.4-24.4^{*}\end{array}$ & $\begin{array}{l}46.0-66.2 \\
27.0-30.9 \\
54.7-59.7 \\
12.0-19.0 \\
40.3-51.1 \\
20.8-29.1 \\
21.4-25.0\end{array}$ \\
\hline \multicolumn{6}{|l|}{ MERISTICS } \\
\hline $\begin{array}{l}\text { dorsal spines } \\
\text { dorsal rays } \\
\text { anal rays } \\
\text { pectoral rays } \\
\text { gill rakers } \\
\text { lateral line scales } \\
\text { scale rows above } \\
\text { scale rows below } \\
\text { caudal rays } \\
\text { predorsal bones } \\
\text { precaudal vertebrae } \\
\text { caudal vertebrae }\end{array}$ & $\begin{array}{r}12 \\
14 \\
12 \\
17 \\
- \\
70 \\
23 \\
32 \\
18 \\
2 \\
15 \\
20\end{array}$ & $\begin{array}{l}11-12 \\
13-15 \\
11 \\
17 \\
- \\
68-71 \\
24-25 \\
32-34 \\
17-18 \\
2-3 \\
15 \\
20\end{array}$ & $\begin{array}{c}10-12 \\
13-15 \\
11-12 \\
17-19 \\
- \\
65-80 \\
25-30 \\
29-34 \\
17-19 \\
- \\
- \\
-\end{array}$ & $\begin{array}{l}10-12 \\
14-16 \\
11-12 \\
16-19 \\
18-20^{*} \\
65-82 \\
19-28^{*} \\
32-42 \\
17-19^{*} \\
\quad- \\
- \\
-\end{array}$ & $\begin{array}{l}10-12 \\
13-16 \\
11-12 \\
16-19 \\
18-20 \\
65-82 \\
19-30 \\
29-42 \\
17-19 \\
2-3 \\
15 \\
20\end{array}$ \\
\hline
\end{tabular}

* these data from 4-17 specimens (see Table 7). 